\title{
Numerical analysis of the role of radiogenic basement on temperature distribution in the St. Lawrence Lowlands, Québec
}

\author{
Hejuan Liu' ${ }^{1,2}$, Bernard Giroux ${ }^{1 *} \mathbb{D}$, Lyal B. Harris ${ }^{1}$, Steve M. Quenette ${ }^{3,4}$ and John Mansour ${ }^{4}$
}

${ }^{*}$ Correspondence:

bernard.giroux@ete.inrs.ca

${ }^{1}$ Centre - Eau Terre

Environnement, Institut

national de la recherche scientifique, 490 rue de la

Couronne, Québec, QC G1K

9A9, Canada

Full list of author information

is available at the end of the

article

\begin{abstract}
Regions with low or medium surface heat flow in stable cratonic areas, such as in eastern Canada, have received little attention for geothermal energy. In the presence of a high heat-producing basement overlain by a sedimentary cover, however, such areas might be prospective. Their potential will depend on various parameters such as heat production within the basement, thermal conductivity of sedimentary formations, and structural context. In this study, we aim at quantifying the importance of these parameters on temperature distribution at depth for a model representative of the St. Lawrence Lowlands, Québec, where locally anomalously higher heat flow has been observed and a 3D model of sedimentary cover is available. Scenarios involving physical properties from neighbouring Grenvillian domains are considered: Portneuf-Mauricie domain with radiogenic heat production of $0.94-5.83 \mu \mathrm{W} \mathrm{m}^{-3}, 0.02-4.13 \mu \mathrm{W} \mathrm{m}^{-3}$ for the Morin Terrane, and $0.34-1.96 \mu \mathrm{W} \mathrm{m}^{-3}$ for the Parc des Laurentides domain. The impact of radiogenic heating on temperature distribution at depth was simulated using the Underworld 2 numerical modeling code. Results show that at $5 \mathrm{~km}$ depth, the range of temperature difference is $22^{\circ} \mathrm{C}$ for all modeled scenarios. In addition, the benefit of the thermal blanket effect of the sedimentary cover can be significant, but depends strongly on the contrast in thermal conductivity between the basement and the cover, as well as on the structural context, and less on heat production in the basement. Finally, depth of the $120^{\circ} \mathrm{C}$ isotherm varies by up to $1 \mathrm{~km}$ for the scenarios considered; carefully assessing the boundary conditions therefore, appears critical in an exploration context.
\end{abstract}

Keywords: Deep geothermal potential, St. Lawrence Lowlands, Radiogenic Grenvillian basement, Temperature distribution, Underworld2 numerical modeling

\section{Introduction}

Active volcanic or magma-related systems possessing a high heat flow at plate margins have received attention for geothermal energy because of their high temperature at shallow depths (Capuno et al. 2010). Regions with low or medium surface heat flow in stable cratonic areas, such as in eastern Canada, have received much less attention. In some such regions, there, however, may still be potential to develop high-temperature "Hot Dry Rock" geothermal resources (summarized by Hillis et al. 2004), especially 
when there is a high heat-producing basement, e.g. granites rich in radiogenic elements (Costain et al. 1980). The Cooper Basin in Australia is an example of such "Hot Dry Rock" geothermal exploration where high heat producing $\left(3.8-8.7 \mu \mathrm{W} \mathrm{m}{ }^{-3}\right)$ basement granites, and thick sedimentary rocks with low thermal conductivity act as a "thermal blanket", give rise to temperature anomalies in the range of $240{ }^{\circ} \mathrm{C}$ at $3.5 \mathrm{~km}$ depth (Beardsmore 2005; Hillis et al. 2004; Horspool et al. 2012). There has, however, been little previous study of whether there is potential for "Hot Dry Rock" geothermal resources in eastern Canada.

In Canada, the utilization of geothermal energy has increased significantly during the last decade, although it is mainly limited to low enthalpy systems (Raymond et al. 2015; Thompson 2010). Compared to other countries, such as the USA, Indonesia, Philippines, Mexico, and New Zealand, the development and application of geothermal power in Canada lags because of the lack of federal and provincial support (Thompson et al. 2015). There is, however, great potential for developing geothermal power in western Canada, especially in British Columbia and SW Yukon (Grasby et al. 2012; Thompson et al. 2015) which are along the Pacific Ring of Fire. In contrast, the Canadian Shield of eastern Canada and the Appalachian orogen on its SE margin have an overall low heat flow of less than $60 \mathrm{~mW} \mathrm{~m}^{-2}$ (Drury et al. 1987; Fou 1969; Grasby et al. 2012; Jaupart et al. 1998; Majorowicz and Minea 2012; Mareschal et al. 2000; Misener et al. 1951; Pinet et al. 1991; Saull et al. 1962), making the utilization of geothermal power from deep geothermal resources less attractive.

Grasby et al. (2012) concluded that there is little potential for high-temperature geothermal resources in the province of Québec because of the generally low heat generation $\left(0.7-0.8 \mu \mathrm{W} \mathrm{m}{ }^{-3}\right)$ and high thermal conductivity $\left(>3 \mathrm{~W} \mathrm{~m}^{-1} \mathrm{~K}^{-1}\right)$ of the Precambrian basement rocks, resulting in low geothermal gradients. However, recent evaluations in parts of the St. Lawrence Lowlands have suggested differently, especially south of Montréal and Trois-Rivières, in the Gaspésie Peninsula, and on Anticosti Island (Majorowicz and Grasby 2010; Majorowicz and Minea 2012, 2013; Minea and Majorowicz 2011, 2012; Perry et al. 2010; Raymond et al. 2012). The local elevated temperatures at depth suggested in these studies are likely due to the presence of radiogenic crystalline gneissic basement. For example, in the N Appalachians ca. $230 \mathrm{~km} \mathrm{NE}$ of Québec City, Gicquel et al. (2015) present a correlation between higher thermal maturation in Appalachian sedimentary rocks (calculated from vitrinite reflectance data,) where they overlie radiogenic migmatitic Grenvillian paragneisses interpreted from aeromagnetic data. Some basement granitoids or alkaline and carbonatite intrusions in the sedimentary cover (e.g., in Oka, Ford et al. 2001) may result in local, high radiogenic heat flow in St. Lawrence Lowlands, and N Appalachian orogen. Preliminary interpretations of aeromagnetic and gravity data suggest the possibility for lateral offset of Grenvillian basement rocks along ductile shear zones that parallel the St. Lawrence River (Gicquel et al. 2015); therefore, direct extrapolation of basement domains in the Grenville Province beneath the St. Lawrence Lowlands is not yet possible. Our research has focused on the general problem of whether radiogenic rocks in basement to the St. Lawrence Lowlands in the region south of Trois-Rivières (Fig. 1) may play a significant role in affecting the temperature distribution at depth and whether thermal modeling may help constrain the nature of basement in this area. 


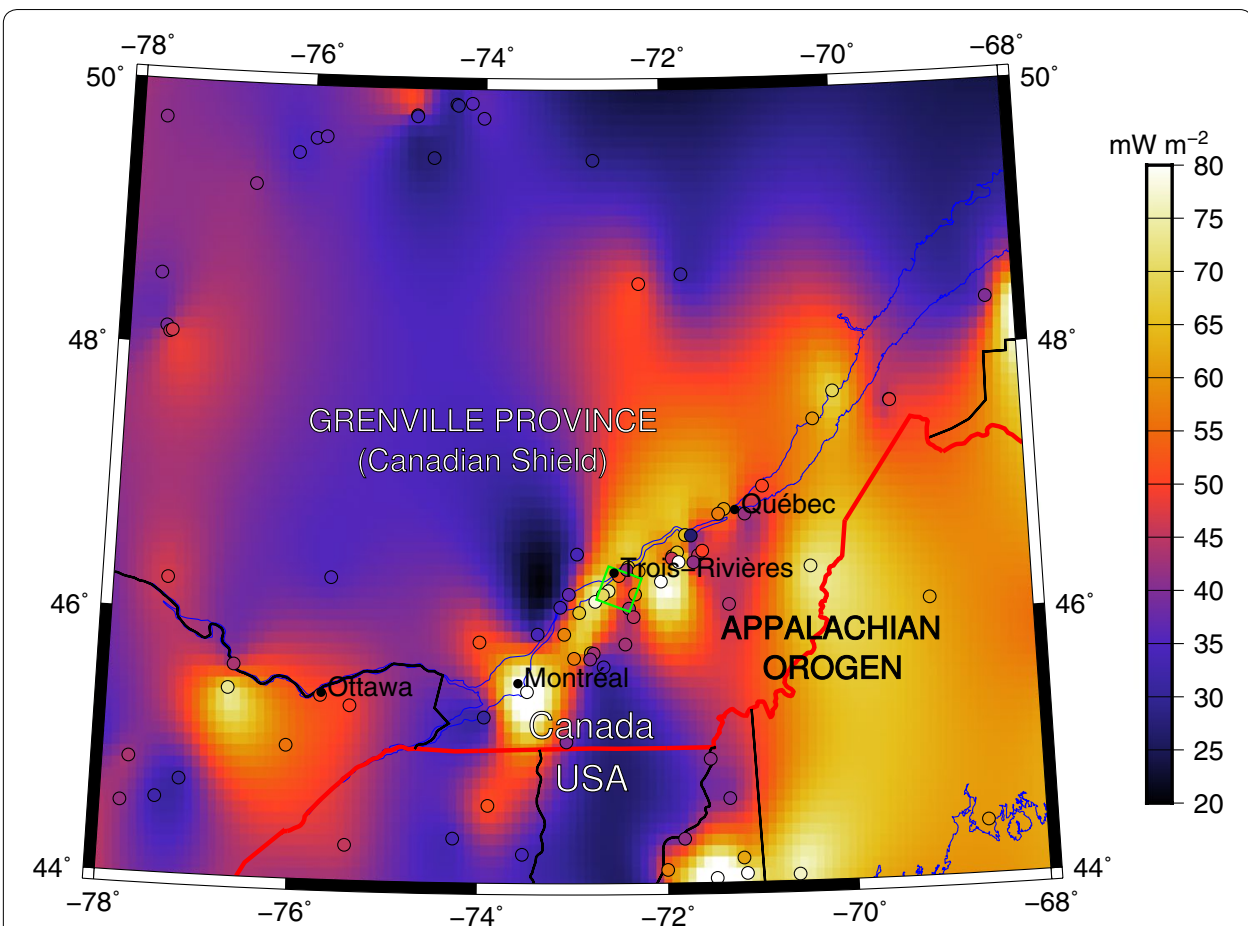

Fig. 1 Surface heat flow in southwestern Québec. Open circles show the data points of heat flow values based on Perry et al. (2010) and references therein; Bédard et al. (2016); SMU Geothermal Laboratory (2018); Jean-Claude Mareschal, pers. comm. Green box is the study area

This area was selected, as it was the subject of prior research evaluating the potential for the $\mathrm{CO}_{2}$ storage in the St. Lawrence Lowlands in which petrophysical parameters of the sedimentary rocks were measured and present-day stress field calculated (Bédard et al. 2013b; Konstantinovskaya et al. 2012; Malo et al. 2014), and a 3D GOCAD model (Bédard et al. 2013a) and a structural interpretation of 2D seismic line M2002 (Castonguay et al. 2010) that crosses the area are available. Although a broad overview of depth to basement and main faults has been documented by Thériault et al. (2005), the detailed lithological composition of the Grenville Province basement underlying the Cambro-Ordovician platform sequence in this region is not well constrained.

A sensitivity study was undertaken using the Underworld2 geothermal modeling software (Mansour et al. 2018; Moresi et al. 2007; Quenette et al. 2015) on small scale 3D model, using the area $\mathrm{S}$ of Trois-Rivières as representing a geological setting typical of the St. Lawrence Lowlands to investigate the impacts of: (1) a homogeneous basement with properties representative of the different basement domains (each with different concentrations of uranium, thorium, and potassium and variable thermal conductivity) that may occur beneath the Saint Lawrence Lowlands; (2) intrusions within basement; (3) the thermal blanket effect of sedimentary cover; and (4) boundary conditions, especially the temperature at the bottom boundary of the model. 


\section{Geological setting}

\section{St. Lawrence Lowlands}

The St. Lawrence Lowlands in southern Québec is composed of Cambrian to Ordovician sedimentary rocks that overly a Mesoproterozoic Grenvillian metamorphic and intrusive basement (geology of basement domains is discussed in the next section). The St. Lawrence Lowlands basin developed during the intracratonic rifting of the Rodinia supercontinent related to the opening of the Iapetus ocean during the Neoproterozoic to Early Cambrian (Hersi et al. 2003; Tremblay et al. 2003). During the Cambrian to early Ordovician, it evolved into an oceanic basin (Kumarapeli 1985) characterized by a syn-rift and passive continental margin succession (Lavoie et al. 2014). During the Middle-to-Late Ordovician onset of Taconian thrusting in the initial stage of Appalachian orogenesis, it evolved into a foreland basin characterized by the deposition of carbonates, shales, and clastic sequences (Bernstein 1991; Lavoie et al. 2009, 2014; Tremblay et al. 2003). Deposition in the St. Lawrence Lowlands ended following the emplacement of large ophiolitic nappes onto Laurentia and the accretion of volcanic arcs and continental blocks induced by the closure of the Iapetus Ocean and convergence between Laurentia and Gondwana Taconian Orogeny (De Souza et al. 2014; Lavoie and Chi 2010; Rimando and Benn 2005; Rocher and Tremblay 2001).

From bottom to top, the sedimentary sequence of the St. Lawrence Lowlands is: Potsdam (PO), Beekmantown (BK), Trenton-Black River-Chazy (Tr-BR-Ch), Utica and Sainte-Rosalie-Lorraine-Queenston (SR-LO-QT) groups which are mainly composed of sandstones, dolomites, limestone, shale, and siltstone, respectively (Clark 1972; Globensky 1987; Lavoie et al. 2009); see Figs. 2 and 3.

Densities and radiogenic element concentrations of rocks representative of the overlying sedimentary formations are listed in Table 1. Utica shales have the highest concentrations of radiogenic elements, with uranium, thorium and potassium in the range of 2.59-3.41 ppm, 2.9-9.8 ppm, and 0.29-3.42\%, respectively. Dolomites from the Beekmantown group also have high concentration of radiogenic elements. There is only one measurement for uranium and thorium in the uppermost cap rock (SR-LO-QT groups), which is relatively high but likely not representative. Thermal conductivities of the sedimentary rocks show that the sandstones of the Potsdam group have the highest values in the range $4.77-6.9 \mathrm{~W} \mathrm{~m}^{-1} \mathrm{~K}^{-1}$, followed by the dolomites of the Beekmantown group in the range of $2.7-4.24 \mathrm{~W} \mathrm{~m}^{-1} \mathrm{~K}^{-1}$ while for other groups with an average value less than $3.0 \mathrm{~W} \mathrm{~m} \mathrm{~m}^{-1} \mathrm{~K}^{-1}$.

\section{Grenvillian basement}

The Grenville Province of western Québec is composed of high-grade metamorphic terranes accreted to the SE Laurentian margin (Davidson 1984; Dufréchou et al. 2014; Rivers 1997, 2015). Grenvillian rocks outcropping N of our study area comprise the generally $\mathrm{N}-\mathrm{S}$ trending Portneuf-Mauricie and Parc des Laurentides domains on the E margin of the Mékinac-Taureau dome, along with an eastern extremity of the Morin terrane on the dome's southern and eastern margins (Nadeau and Brouillette 1994, 1995; Nadeau et al. 2008; Sappin et al. 2009), as portrayed in Fig. 4. 


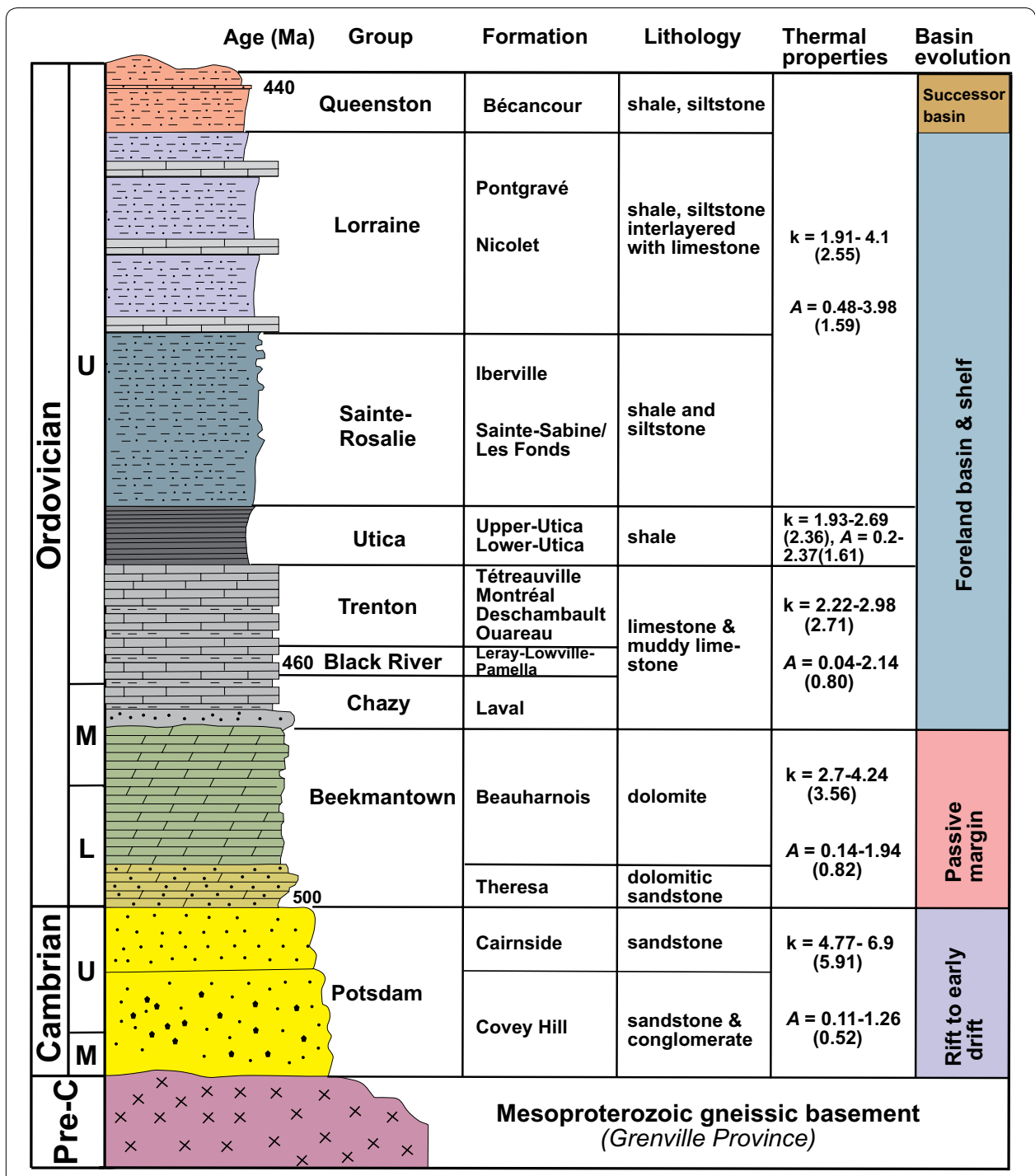

Fig. 2 Stratigraphy of St. Lawrence Lowlands. Stratigraphy of St. Lawrence Lowlands, with lithology, thermal

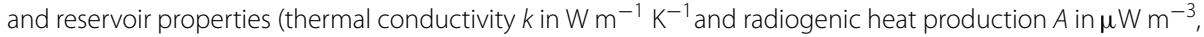
values of the minimum, maximum and mean are in parentheses; Perm = permeability). Basin evolution is modified after (Comeau et al. 2012), combining data obtained from Bédard et al. (2016), Globensky (1987), Hersi et al. (2003), Hofmann (1972), Nasr (2016), Pinti et al. (2011), Rocher and Tremblay (2001)

The concentration of uranium, thorium, and potassium of ten basement core samples of orthogneiss, granite \pm pegmatite, and quartzite from wells located in or

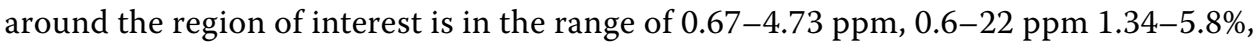
respectively (Table 2).

\section{Portneuf-Mauricie (PM) domain}

The Portneuf-Mauricie domain (PM) region comprises (1) metasedimentary and metavolcanic rocks of the Montauban group, including amphibolite facies quartzofeldspathic gneiss, quartzite, marble, and calc-silicate rocks and andesitic to rhyolitic volcanics and (2) the La Bostonnais Complex plutons, including the de Lapeyrère and Gagnon 


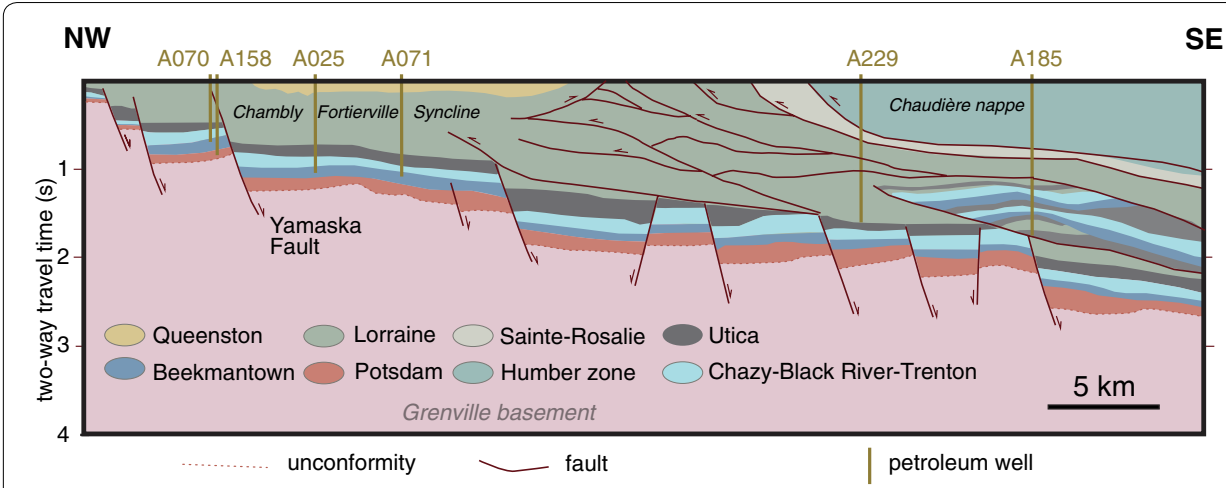

Fig. 3 Interpretation of seismic profile M2002. Interpretation of seismic profile M2002 crossing the modeled region (simplified from Castonguay et al. (2010). Bottom hole temperatures after Harrison correction in ${ }^{\circ} \mathrm{C}$ for wells A070, A229 and A185 are shown in the profile

Table 1 Density, concentration of radiogenic elements, and thermal conductivity of sedimentary rocks of the St. Lawrence Lowlands, with the minimum, maximum values and average in parentheses

\begin{tabular}{|c|c|c|c|c|c|}
\hline Groups & $\rho_{r}\left(\mathrm{~kg} \mathrm{~m}^{-3}\right)$ & $C_{U}(\mathrm{ppm})$ & $C_{T h}(\mathrm{ppm})$ & $C_{K}(\%)$ & $k\left(\mathrm{~W} \mathrm{~m}^{-1} \mathrm{~K}^{-1}\right)$ \\
\hline 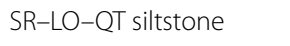 & (2602) & 3.1 & 10.2 & & $(2.55)$ \\
\hline Utica shale & $2700-2710(2705)$ & $2.59-3.41(2.9)$ & $2.9-9.8(7.4)$ & $0.29-3.42(2.33)$ & $1.93-2.46(2.36)$ \\
\hline TR-BR-Ch lime & $2630-2700(2680)$ & $0.2-6.6(1.6)$ & $2.4-4.7(3.55)$ & $0.04-2.66(0.67)$ & $2.22-2.98(2.71)$ \\
\hline eekmantown dolomite & $2640-2810(2717)$ & $0.07-3.08(2.0)$ & $3-14(7.5)$ & $0.19-6.26(2.08)$ & $2.7-4.24(3.56)$ \\
\hline Potsdam sandstone & $2540-2640(2602)$ & $0.4-0.45(0.43)$ & $1.38-1.4(1.39)$ & $0.05-2.3(0.32)$ & $4.77-6.9(5.91)$ \\
\hline
\end{tabular}

Densities of sedimentary rocks are based on measurements of 32 samples by Nasr (2016); averages are in parenthesis. Radiogenic element data are from Owen and Greenough (2008), Pinti et al. (2011), Rivard et al. (2002), Vautour et al. (2015) as well as new ICP-MS and ICP-OES measurements. Thermal conductivity data of sedimentary rocks are from Nasr (2016) and Perozzi et al. (2016)

gabbronorites, granite, quartz monzonite, quartz syenite, and pegmatite which contain high concentrations of $\mathrm{K}_{2} \mathrm{O}$ and Th (Corrigan 1995; Gautier 1993; Nadeau et al. 1992; Sappin 2012). Montauban group rocks are interpreted as part of a $1.45 \mathrm{Ga}$ arc-back-arc complex into which the La Bostonnais complex plutons were intruded between 1.40 and $1.37 \mathrm{Ga}$ after deformation and metamorphism of the Montauban group (Nadeau and van Breemen 1994; Sappin 2012; Sappin et al. 2009, 2014). Physical properties of Portneuf-Mauricie domain rocks are listed in Table 3. There are limited thermal conductivity data in the literature; therefore, five additional measurements were performed using a KD2 Pro probe and lab thermal properties analyzer.

\section{Morin Terrain (MT) and Mékinac Taureau domain}

The Morin Terrane in our study area (the Shawinigan domain of Corrigan and van Breemen (1997)) is characterized by Grenville Supergroup paragneisses and quartzite along with granitic and granodioritic gneiss and metavolcanics. The main area of exposure of the Morin Terrane W of our study area underwent regional ca. 1280 Ma deformation and metamorphism prior to diapiric emplacement of 1165-1135 Ma anorthosite-mangerite-charnockite-granite (AMCG) suite intrusions (Corrigan and van Breemen 1997; Corriveau and van Breemen 2000; Emslie and Hunt 1990; 


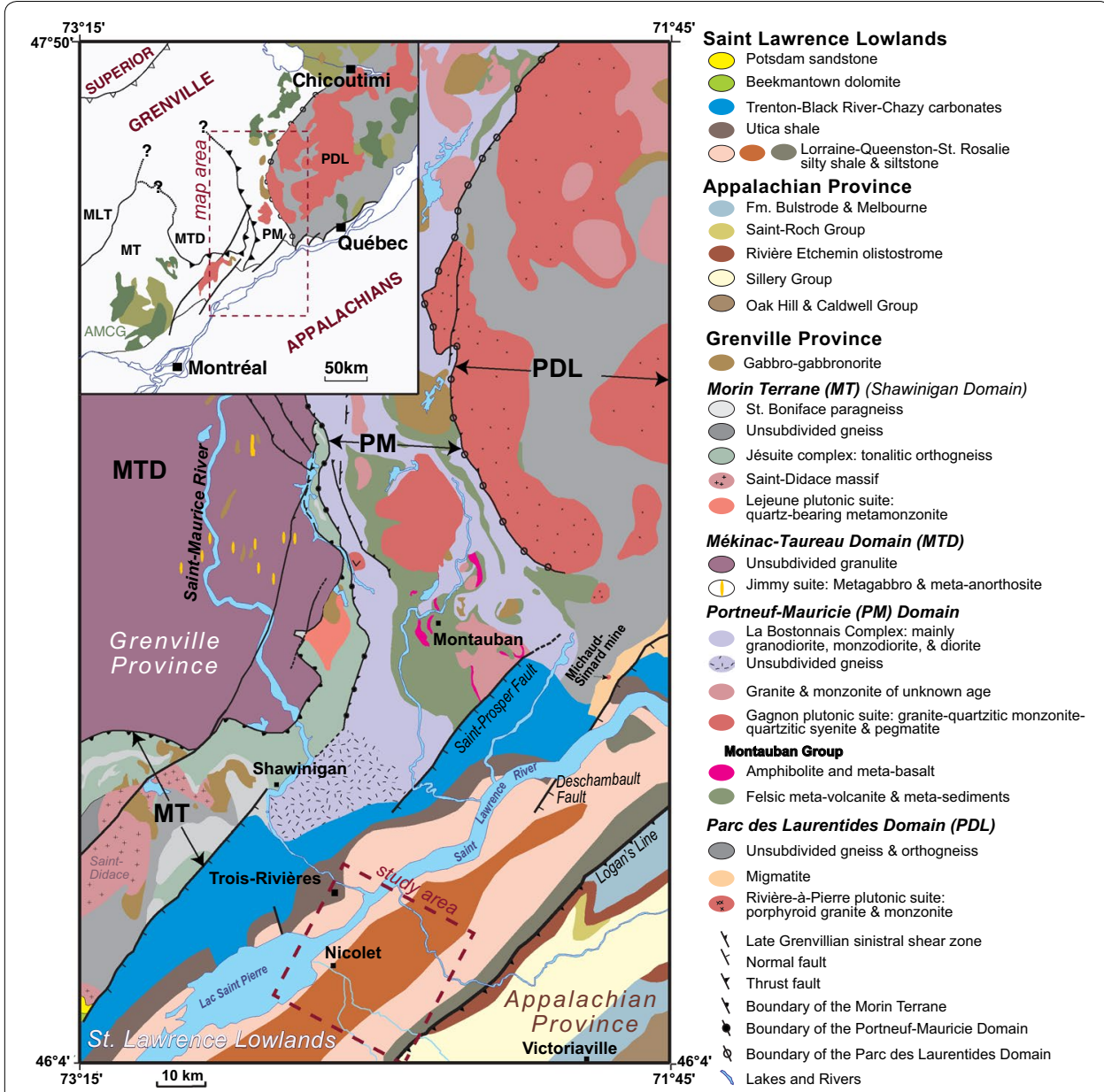

Fig. 4 Simplified regional geology. Geology of the Grenville Province is taken from Nadeau and Brouillette (1994, 1995); St. Lawrence Lowlands and Appalachian Province geology is from SIGÉOM (2018). Dashed maroon square indicates the study area. Inset map is modified after (Charlier et al. 2010)

Table 2 Concentration of radiogenic elements for basement rocks obtained from wells located south of Trois-Rivières from ICP-MS and ICP-OES analyses undertaken in our study

\begin{tabular}{lllllll}
\hline Well no. & Long. & Lat. & Lithology & $\boldsymbol{C}_{\boldsymbol{U}}$ (ppm) & $\boldsymbol{C}_{\boldsymbol{T h}}$ (ppm) & $\boldsymbol{C}_{\boldsymbol{K}}$ (\%) \\
\hline A027 & 46.3186 & -72.4857 & Granitic gneiss & 4.73 & 11.3 & 3.93 \\
A126 & 46.1539 & -72.6774 & Pegmatite & 2.19 & 22 & 5.80 \\
A128 & 46.3356 & -72.6103 & Granite & 1.58 & 6.7 & 3.92 \\
A129 & 46.2895 & -72.7064 & Quartzite & 0.67 & 1.4 & 1.34 \\
A130 & 46.3068 & -72.6997 & Granitic gneiss & 0.47 & 0.6 & 2.23 \\
A167 & 46.6216 & -71.7040 & Granite & 1.01 & 3.2 & 2.63 \\
A175 & 46.8181 & -71.3353 & Granite & 1.96 & 9.0 & 4.02 \\
A186 & 46.1850 & -72.6439 & Pegmatite & 1.59 & 5.9 & 3.91 \\
A197 & 46.1814 & -72.6714 & Granite & 0.87 & 5.2 & 6.59 \\
A222 & 46.1819 & -72.3201 & Granitic gneiss & 0.92 & 3.4 & 2.05 \\
\hline
\end{tabular}


Table 3 Density, radiogenic element concentration and thermal conductivity data for rocks of the Portneuf-Mauricie domain

\begin{tabular}{|c|c|c|c|c|c|}
\hline Basement rock & $\rho_{r}\left(\mathrm{~kg} \mathrm{~m}^{-3}\right)$ & $C_{U}(\mathrm{ppm})$ & $C_{T h}(\mathrm{ppm})$ & $C_{K}(\%)$ & $k\left(\mathrm{~W} \mathrm{~m}^{-1} \mathrm{~K}^{-1}\right)$ \\
\hline Amphibolite (12) & $\begin{array}{l}2860-3090 \\
(3010)\end{array}$ & $0.5-3(2.2)$ & $3-6(3.8)$ & $0.19-0.92(0.41)$ & $2.27-2.32(2.3)$ \\
\hline Basalt (3) & - & - & 3 & $0.49-3.14(1.47)$ & $2.42-4.91(3.32)$ \\
\hline Diorite (10) & $\begin{array}{l}2730-2970 \\
(2840)\end{array}$ & $0.5-2.2(1.33)$ & $0.55-5.2(4.08)$ & $0.11-4.75(1.64)$ & $3.35-3.92(3.64)$ \\
\hline $\begin{array}{l}\text { Gabbro-gab- } \\
\text { bronorite (21) }\end{array}$ & $\begin{array}{l}2600-3530 \\
(2995)\end{array}$ & $0.05-0.6(0.35)$ & $0.2-3.6(1.45)$ & $0.1-2.32(0.47)$ & $1.84-4.72(3.02)$ \\
\hline Granite (22) & $\begin{array}{l}2620-2760 \\
(2670)\end{array}$ & $0.5-4.9(1.41)$ & $1.2-56(6.18)$ & $0.5-5.59(3.6)$ & $1.7-4.0(2.76)$ \\
\hline $\begin{array}{l}\text { Granitic gneiss } \\
\text { (37) }\end{array}$ & $\begin{array}{l}2530-3160 \\
(2650)\end{array}$ & $0-22(3.33)$ & $0.8-55.9(9.35)$ & $0.2-4.9(2.12)$ & $1.53-5.88(2.24)$ \\
\hline Iherzolite (4) & - & 0.2 & $0.4-0.7(0.55)$ & $0.14-0.19(0.17)$ & - \\
\hline Migmatite (4) & - & $0.5-4.5(1.85)$ & $0.2-14.4(5.18)$ & $0.2-1.3(1.0)$ & - \\
\hline Pyroxenite (2) & - & $0-0.2(0.1)$ & $0-0.2(0.1)$ & $0.08-0.09(0.085)$ & - \\
\hline Paragneiss (46) & $\begin{array}{l}2580-3350 \\
(2790)\end{array}$ & $0-3.9(2.4)$ & $0-14(7.09)$ & $0-3.73(1.83)$ & $1.53-5.88(2.24)$ \\
\hline Pegmatite (2) & $\begin{array}{l}2470-2810 \\
(2630)\end{array}$ & $\begin{array}{c}640.4-1202 \\
(921.2)\end{array}$ & $\begin{array}{l}1141-1151 \\
(1146)\end{array}$ & - & $2.28-2.98(2.46)$ \\
\hline Quartzite (5) & $\begin{array}{l}2580-3350 \\
(2790)\end{array}$ & 3 & $3-11(6.6)$ & $0.48-1.73(1.42)$ & $6.08-6.38(6.23)$ \\
\hline $\begin{array}{l}\text { Quartz monzo- } \\
\text { nite (9) }\end{array}$ & $\begin{array}{l}2600-2760 \\
(2700)\end{array}$ & $0.5-1.8(1.0)$ & $3.0-3.2(3.03)$ & $1.48-4.52(3.64)$ & $3.35-3.92(3.64)$ \\
\hline Websterite (3) & - & $0.05-0.2(0.12)$ & $0.05-0.7(0.42)$ & $0.11-0.54(0.28)$ & - \\
\hline
\end{tabular}

Data sources: densities are from Emslie and Ermanovics (1975), Feininger and Goodacre (1995), Kearey (1978), Paradis (2004). Radiogenic element concentration data are from 163 samples from the SIGÉOM (2018) database. Thermal conductivity data are from Mareschal (2018), Jessop et al. (2005). Average values are in parenthesis. Number of samples for radiogenic element concentration is given in parenthesis after rock type

Martignole and Schrijver 1977). The domal structure of the Mékinac Taureau domain (Fig. 4), interpreted as being exhumed during crustal extension by Soucy La Roche et al. (2015), has subsequently been attributed from geophysical data to the presence of an underlying, contemporaneous AMCG body by Dufréchou (2017), which our unpublished geophysical data support. Sinistrally oblique extension along the Tawachiche shear zone (TSZ) on the E margin of the Morin Terrane, marking the mapped contact with the Portneuf-Mauricie domain, occurred between 1065 and $1035 \mathrm{Ma}$ (Soucy La Roche et al. 2015). The Shawinigan norite, the Lejeune complex and the St. Didace complex intrude Morin Terrane granulites on the $\mathrm{S}$ margin of the Mékinac-Taureau dome between 1080 and 1056 Ma (Nadeau et al. 2008; Nadeau and van Breemen 2001; Soucy La Roche 2014; Soucy La Roche et al. 2015).

Paradis (2004) presents density data for granite $\left(2630-2710 \mathrm{~kg} \mathrm{~m}^{-3}\right.$, average $=$ 2668.3), quartzite $\left(2640-2730 \mathrm{~kg} \mathrm{~m}^{-3}\right.$, average $\left.=2685\right)$, charnockite $(2700-2750$ $\mathrm{kg} \mathrm{m}^{-3}$, average $\left.=2733\right)$, anorthosite $\left(2670-2830 \mathrm{~kg} \mathrm{~m}^{-3}\right.$, average $\left.=2726\right)$ and paragneiss $\left(2930-3100 \mathrm{~kg} \mathrm{~m}^{-3}\right.$, average $\left.=2990\right)$; the overall bulk density of the Morin Terrane is in the range $2580-3350 \mathrm{~kg} \mathrm{~m}^{-3}$, with an average of $2760 \mathrm{~kg} \mathrm{~m}^{-3}$. Table 4 contains concentration of radiogenic elements data collected from the SIGÉOM (2018) and Mareschal (2018) databases, Mareschal and Jaupart (2013), Peck (2012), as well as field and laboratory measurements performed in this study. Radiogenic 
Table 4 Concentration of radiogenic elements for outcropping rocks of the Morin Terrane (including samples from outside our study area)

\begin{tabular}{llll}
\hline Rock type & $\boldsymbol{C}_{\boldsymbol{U}}(\mathbf{p p m})$ & $\boldsymbol{C}_{\boldsymbol{T h}}$ (ppm) & $\boldsymbol{C}_{\boldsymbol{K}}(\%)$ \\
\hline Anorthosite (7) & - & - & $0.07-1.0$ \\
Amphibolite (23) & $0.2-17.7$ & $1.7-35.1$ & $0.9-4.5$ \\
Diorite (4) & $1.7-4.5$ & $3.6-38$ & $1.8-5.0$ \\
Granite (7) & $0.9-13.9$ & $2.2-31$ & $0.5-6.29$ \\
Granitic gneiss (36) & $0.2-3.95$ & $0.25-35.5$ & $0.9-5.9$ \\
Granodiorite gneiss (4) & $0.54-1.35$ & $0.6-4.7$ & $2.71-3.35$ \\
Mangerite (1) & 0.5 & 0.2 & 0.36 \\
Marble (20) & $2.1-3.4$ & - & $0.11-7.91$ \\
Mixed gneiss (91) & $0-9.2$ & $0.1-35.9$ & $0-5.8$ \\
Pyroxenite (4) & $0.5-3.4$ & - & 0.01 \\
Quartz-monzonite (1) & 0.5 & - & 5.96 \\
Quartzite (10) & $1.7-2.4$ & - & $0.05-0.22$ \\
Pegmatite (5) & $0.3-59.3$ & $11.2-421.5$ & $2.8-7.1$ \\
\hline
\end{tabular}

Table 5 Concentration of radiogenic elements of rocks from Rivière-à-Pierre suite in the Parc des Laurentides domain Data sources: (SIGÉOM 2018; Higgins and van Breemen 1996)

\begin{tabular}{llll}
\hline Rock type & $\boldsymbol{C}_{\boldsymbol{U}}(\mathbf{p p m})$ & $\boldsymbol{C}_{\boldsymbol{T h}}(\mathbf{p p m})$ & $\boldsymbol{C}_{\boldsymbol{K}}(\%)$ \\
\hline Amphibolite (1) & 0.8 & 3 & 0.78 \\
Charnockite (5) & - & - & $2.94-4.25$ \\
Gabbro (2) & $0.5-0.7$ & 3 & $2.25-4.57$ \\
Granite (16) & $0.5-1.9$ & $2.2-14$ & $1.37-5.48$ \\
Granitic gneiss (7) & $0.5-1.8$ & $3-4.1$ & $0.99-3.87$ \\
Mangerite (5) & $0.5-1.0$ & $2.1-2.2$ & $2.17-3.44$ \\
Quartz-monzonite (7) & $0.5-1.2$ & $3-10$ & $4.23-5.14$ \\
Quartzite (1) & 1.7 & 3 & 4.26 \\
Bulk rock & $0.5-1.9(1.18)$ & $2.1-14(4.05)$ & $0.78-5.48(3.55)$
\end{tabular}

element concentrations are $\mathrm{U}=0.01-4.5$ (average $=1.67) \mathrm{ppm}$, in $\mathrm{Th}=0.2-31$ (average $=10.7) \mathrm{ppm}$ and $\mathrm{K}=0.01-7.91 \%$ (average: $2.43 \%$ ). Thermal conductivities range between 2.36 and $4.58 \mathrm{~W} \mathrm{~m}^{-1} \mathrm{~K}^{-1}$, with an average value of $2.89 \mathrm{~W} \mathrm{~m}^{-1} \mathrm{~K}^{-1}$ (Jessop et al. 2005). Additional measurements for nine samples obtained from the Shawinigan domain vary between 2.017 and $3.924 \mathrm{~W} \mathrm{~m}^{-1} \mathrm{~K}^{-1}$, with an average value of $2.648 \mathrm{~W} \mathrm{~m}^{-1} \mathrm{~K}^{-1}$.

\section{Parc des Laurentides domain}

The Parc des Laurentides domain (PDLD) is mainly composed of the quartz-monzonite, porphyritic granite, mangeritic-charnockitic-granitic and granodioritic orthogneiss (Hébert and Nadeau 1995; Paradis 2004; Sappin 2012). Its western boundary separated from the Portneuf-Mauricie domain was obliterated by large granitic intrusions of the $1058 \pm 1$ Ma Rivière-à-Pierre suite (Hébert and Nadeau 1995).

The bulk density of the PDLD lies between 2575 and $2775 \mathrm{~kg} \mathrm{~m}^{-3}$, with a mean density of $2680 \mathrm{~kg} \mathrm{~m}^{-3}$ (Paradis 2004). The radioelement data for rocks from the Rivière-àPierre suite are shown in Table 5. Uranium, thorium, and potassium concentrations are 
$0.5-1.9 \mathrm{ppm}, 2.1-14 \mathrm{ppm}$, and $0.78-5.48 \%$, respectively. The thermal conductivity of 3 samples obtained from the PDLD is in the range of $3.02-5.15 \mathrm{~W} \mathrm{~m}^{-1} \mathrm{~K}^{-1}$, with an average value of $3.8 \mathrm{~W} \mathrm{~m}^{-1} \mathrm{~K}^{-1}$ (Jessop et al. 2005).

\section{Method}

\section{Model definition}

In the absence of fluid flow, the heat equation with a radiogenic source term is (Jaupart and Mareschal 2011)

$$
\rho_{r} C_{p} \frac{\partial T}{\partial t}=\nabla \cdot(k \nabla T)+A,
$$

where $T$ is temperature $\left({ }^{\circ} \mathrm{C}\right), t$ is time $(\mathrm{s}), k$ is thermal conductivity $\left(\mathrm{W} \mathrm{m}^{-1} \mathrm{~K}^{-1}\right), \rho_{r}$ is density $\left(\mathrm{kg} \mathrm{m}^{-3}\right), C_{p}$ is specific heat $\left(\mathrm{J} \mathrm{kg}^{-1} \mathrm{~K}^{-1}\right)$ and $A$ is heat production $\left(\mathrm{W} \mathrm{m}^{-3}\right)$ calculated from the concentration of radiogenic elements. Symbol $\nabla \cdot$ is the divergence operator and $\nabla T$ the temperature gradient. In the following, we assume a steady-state regime. The time-dependence term, therefore, vanishes, which yields

$$
\nabla \cdot(k \nabla T)=-A .
$$

Heat production is considered using the following empirical function (Rybach 1976, 1988):

$$
A=\rho_{r}\left(9.52 C_{u}+2.56 C_{T h}+3.48 C_{K}\right) \times 10^{-5},
$$

where $C_{u}$ is the uranium content (ppm), $C_{T h}$ is the thorium content (ppm), and $C_{K}$ is the potassium content (\%). Thermal conductivity is also assumed to be temperature dependent. The correction of Sekiguchi (1984) was used to take into account this dependence. According to Lee and Deming (1998), this correction is applicable to arbitrary rocks over the temperature range $0-300^{\circ} \mathrm{C}$. It is given by

$$
k=\left(\frac{T_{0} T_{m}}{T_{m}-T_{0}}\right)\left(k_{0}-k_{m}\right)\left(\frac{1}{T}-\frac{1}{T_{m}}\right)+k_{m}
$$

where $T$ is the in situ temperature $(\mathrm{K}), k_{0}$ is the thermal conductivity at laboratory temperature, $T_{0}$ is the laboratory temperature $(\mathrm{K}), k_{m}$ and $T_{m}$ are calibration coefficients, respectively, equal to $1.8418 \mathrm{~W} \mathrm{~m}^{-1} \mathrm{~K}^{-1}$ and $1473 \mathrm{~K}$.

The geothermal module of the 3D geodynamic modeling package Underworld2 (Mansour et al. 2018; Moresi et al. 2007) was used to solve Eq. (2) numerically for temperature distribution. Underworld2 includes a finite-element solver for Eulerian meshes that embed a set of Lagrangian integration points or particles. These particles allow storing material properties and can be moved to follow the deformations of geological materials, through the use of a particle-in-cell method, to map the finite-element integrals in the system. When solving the steady-state heat equation with the Underworld2 module, a standard Gaussian quadrature module is used in place of the particle-in-cell method because there is no deformation.

The area of interest is represented by a simplified $30 \mathrm{~km} \times 30 \mathrm{~km} \times 10 \mathrm{~km}$ geological model representative of the sedimentary configuration of the St. Lawrence Lowlands south of Trois-Rivières (Fig. 1). This model was set up based on available seismic and well-log data and comprises the Grenvillian basement and the overlying 


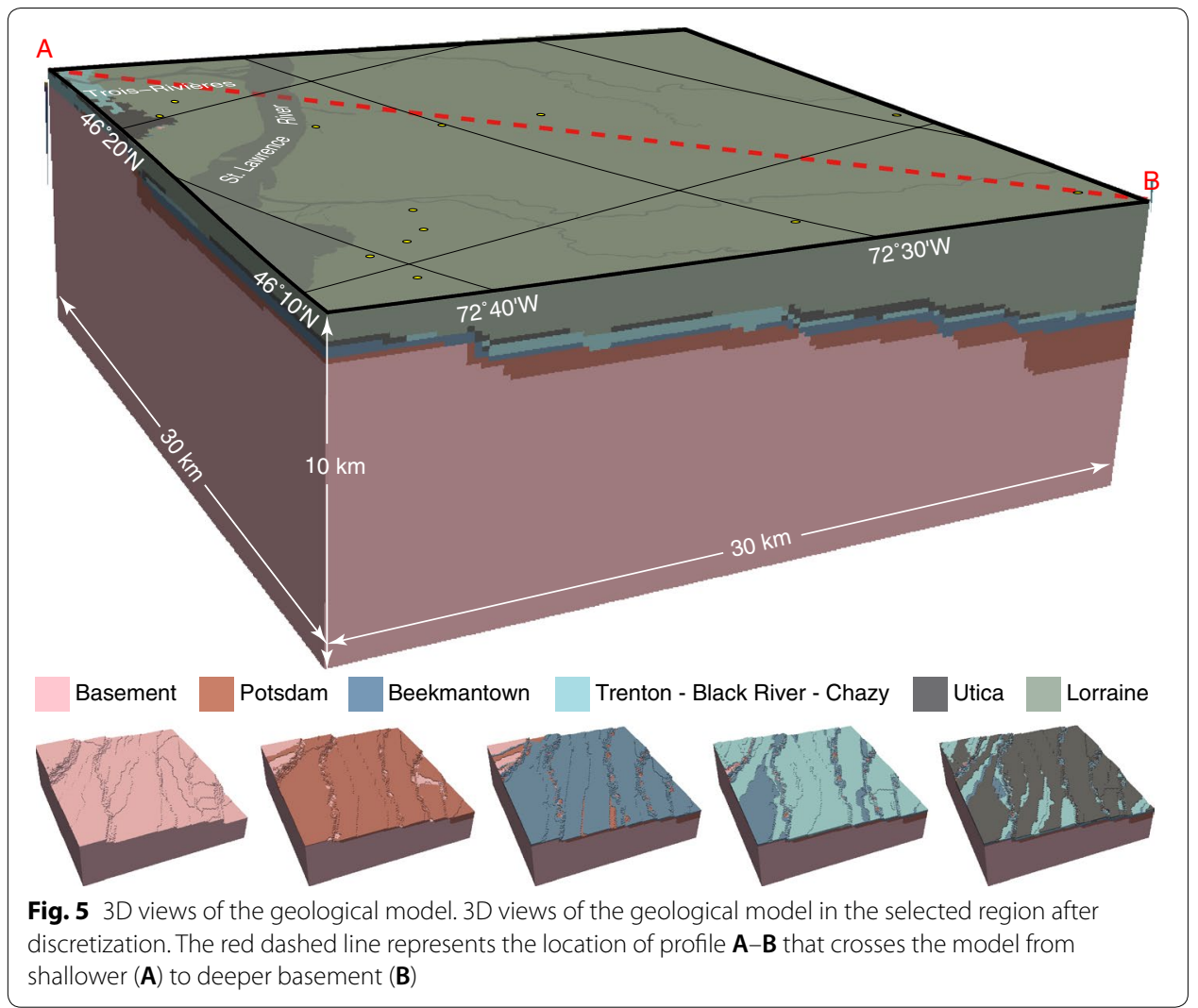

Cambrian-Ordovician sedimentary sequence (see Fig. 5). To perform the sensitivity analysis, various structures are inserted in this model, as described below.

To perform the calculations, the model was discretized in $128 \times 128$ cells in the horizontal directions, and in 64 cells in the vertical direction. The bottom boundary condition was established based on geothermal gradient data in the area as well as bottom hole temperature and surface heat flow data available inside the area of the model. For the St. Lawrence Lowlands, Bédard et al. (2016) found that the geothermal gradient is in the range of $14-35{ }^{\circ} \mathrm{C} \mathrm{km}^{-1}$, with an average of $24.3 \pm 4.9^{\circ} \mathrm{C} \mathrm{km}^{-1}$ (Fig. 6). Within the model limits, 9 bottom hole temperature data are available and 15 heat flow measurements are found (Bédard et al. 2016). For each modeled scenarios described below, a series of modeling runs were done with heat flow imposed at the bottom boundary, with values ranging from 50 to $66 \mathrm{~mW} \mathrm{~m}^{-2}$. The value that yielded a temperature distribution giving the best fit with the $24.3^{\circ} \mathrm{C}$ gradient, the bottom hole temperature data and the surface heat flow data was selected. The fit is defined as the sum of the Relative Root Mean Square Error (rRMSE) of all three variables, with a lower weight (1/2) given to the rRMSE of the gradient because it was obtained with data outside the modeling domain. In all cases, the temperature at the top boundary is specified to be $10{ }^{\circ} \mathrm{C}$ and no-flow Neumann conditions are applied on the sides. Physical properties of the lithological units have been assigned based on the data presented in the geology section. Due to the size of the cells in the numerical mesh, the lithology of each formation must be simplified. Therefore, the main lithology of the Potsdam Group is sandstone, dolomite for the Beekmantown Group, limestone for the Trenton-Black River-Chazy Groups 


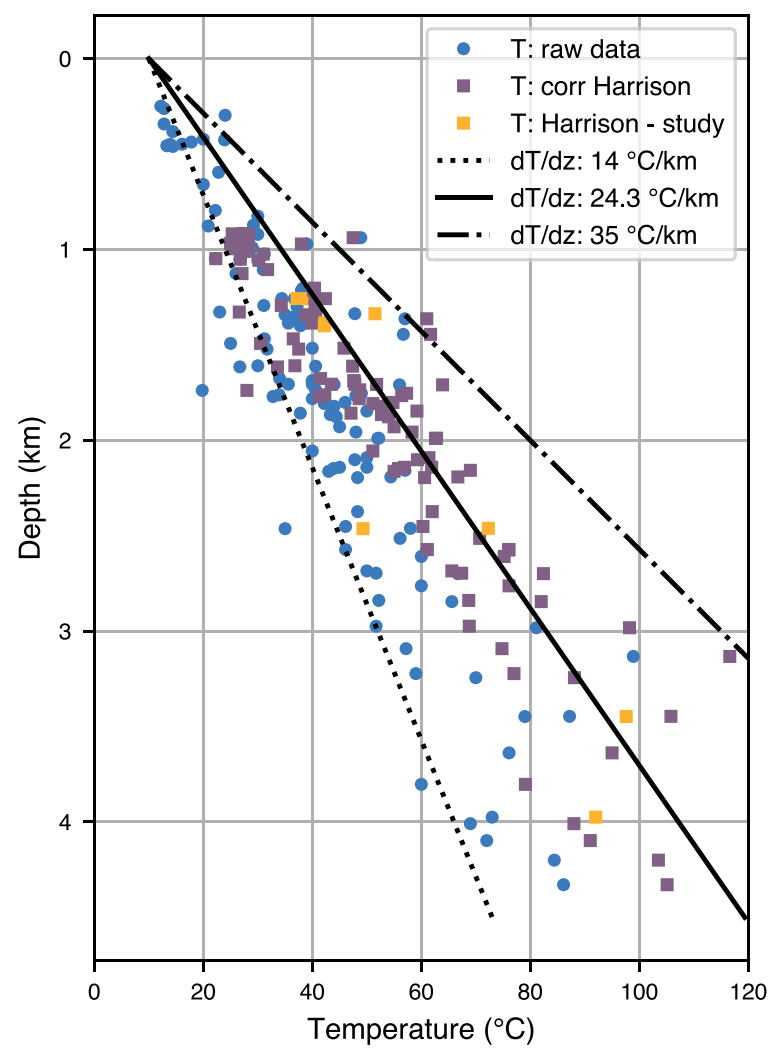

Fig. 6 Temperature-depth relationship. Temperature-depth relationship based on 124 bottom hole temperature data (Bédard et al. 2016) from petroleum wells located in the St. Lawrence Lowlands. The yellow squares are the temperature data after Harrison correction in the modeled region of this paper

(or TR-BR-Ch), shale for the Utica Group, siltstone for the top three groups of SainteRosalie, Lorraine and Queenston (i.e. SR-LO-QT), respectively. For Precambrian basement, the influence of various rock types will be studied, as described next.

\section{Modeled scenarios}

In the study area, the basement is buried by a sedimentary cover varying in thickness between 0.5 and $6.5 \mathrm{~km}$ (see Fig. 3). As previously mentioned, a detailed interpretation of the basement structure is not possible due to scarcity of available data. Therefore, we begin with a simple homogeneous basement with thermal properties obtained from rocks outcropping in the Portneuf-Mauricie domain, which will be referred to as the base case in the simulation study. In the five scenarios presented in this paper, only differences in basement characteristics are considered. For four of the five scenarios, a homogeneous basement is considered, with input data summarized in Table 6. Each scenario is described in more detail below.

\section{Model 1: PM domain basement}

From data listed in Table 3, using Rybach's empirical function (Eq. 3), heat production in the basement is equal to $0.94 \mu \mathrm{W} \mathrm{m}{ }^{-3}$. For this model, a heat flow value of $59 \mathrm{~mW} \mathrm{~m}^{-2}$ 
Table 6 Physical properties of Grenvillian rocks in the PM domain (Model 1), Shawinigan domain (Model 2), PDLD (Model 3) and from well cores (Model 4); average values in parentheses

\begin{tabular}{lllllll}
\hline Basement & $\rho_{\boldsymbol{r}}\left(\mathbf{k g ~ m} \mathbf{~ m}^{-\mathbf{3}}\right)$ & $\boldsymbol{C}_{\boldsymbol{U}}(\mathbf{p p m})$ & $\boldsymbol{C}_{\boldsymbol{T h}}(\mathbf{p p m})$ & $\boldsymbol{C}_{\boldsymbol{K}}(\%)$ & $\boldsymbol{A}\left(\boldsymbol{\mu} \mathbf{W ~ m}^{-\mathbf{3}}\right)$ & $\boldsymbol{k}\left(\mathbf{W ~ m}^{-\mathbf{1}} \mathbf{K}^{-\mathbf{1}}\right)$ \\
\hline Model 1 & $2620-3050$ & $0.05-6.0$ & $0.5-56$ & $0.05-5.59$ & 0.94 & $2.39-3.87$ \\
& $(2790)$ & $(1.61)$ & $(4.65)$ & $(1.64)$ & & $(3.0)$ \\
Model 2 & $2580-3350$ & $0-17.7$ & $0-68.1$ & $0.01-7.91$ & 1.42 & $2.02-3.92$ \\
& $(2760)$ & $(1.91)$ & $(10.38)$ & $(2.92)$ & & $(2.65)$ \\
Model 3 & $2575-2775$ & $0.5-1.9$ & $2.1-14$ & $0.78-5.48$ & 0.91 & $3.02-5.15$ \\
& $(2680)$ & $(1.18)$ & $(4.05)$ & $(3.55)$ & & $(3.8)$ \\
Model 4 & $2580-2620$ & $0.67-4.73$ & $0.6-22$ & $1.34-5.8$ & 1.18 & $2.26-2.71$ \\
& $(2598)$ & $(1.60)$ & $(6.87)$ & $(3.64)$ & & $(2.54)$ \\
\hline
\end{tabular}

at the bottom boundary gave the best fit to the data, with the sum of rRMSE equal to $36 \%$.

\section{Model 2: Morin Terrane basement}

Based on data in Table 4, the calculated heat production for the Morin Terrane is $1.42 \mu \mathrm{W} \mathrm{m}{ }^{-3}$. In this case, a bottom boundary condition of $52 \mathrm{~mW} \mathrm{~m}^{-2}$ was obtained (sum of rRMSE equal to 35\%).

\section{Model 3: Parc des Laurentides domain basement}

An average heat production value of $0.91 \mu \mathrm{W} \mathrm{m} \mathrm{m}^{-3}$ is obtained using the empirical function of Rybach (1988). In this model, the mean concentration of uranium, thorium, and potassium is, respectively, $1.18 \mathrm{ppm}, 4.05 \mathrm{ppm}$ and $3.55 \%$. Heat flow at the bottom boundary is in this case $62 \mathrm{~mW} \mathrm{~m}^{-2}$ (sum of rRMSE equal to $39 \%$ ).

\section{Model 4: basement based on well data}

The parameters of the fourth model are computed from measurements taken on 10 samples obtained from cores collected from wells in the modeled region (Table 2) for which the average bulk density is $2598 \mathrm{~kg} \mathrm{~m}^{-3}$ (Nasr 2016). With the values given in Table 2 for this model, the heat production is $1.18 \mu \mathrm{W} \mathrm{m}{ }^{-3}$. For this model, $53 \mathrm{~mW} \mathrm{~m}^{-2}$ at the bottom boundary gave the best fit to the data (sum of rRMSE equal to $37 \%$ ).

\section{Models 5 and 6: intrusions in the basement}

Two models are used to evaluate the influence of a relatively "hot" intrusion on temperature distribution. The shape of the intrusion is arbitrarily set to a vertical cylinder that crosses the basement in the center of the model. The top of the intrusion is set at $2.4 \mathrm{~km}$, at the interface between the basement and the Potsdam sandstones. In the first model, the radius of the intrusion is $1 \mathrm{~km}$ and its volume is approximately $2.5 \times 10^{10} \mathrm{~m}^{3}$, whereas in the second case the radius is $2 \mathrm{~km}$, for a volume of $9.5 \times 10^{10} \mathrm{~m}^{3}$. Physical properties of the model unit parameters are given in Table 7 . The radiogenic element concentrations for the host rock are assumed to be the same as in Model 1. For the intrusion, properties of granites of the Gagnon pluton (Fig. 4) are used. The bottom boundary condition is the same as for Model 1. 
Table 7 Parameters used for the heterogeneous basement model

\begin{tabular}{llllll}
\hline Unit & $\boldsymbol{C}_{\boldsymbol{U}}(\mathbf{p p m})$ & $\boldsymbol{C}_{\boldsymbol{T h}}(\mathbf{p p m})$ & $\boldsymbol{C}_{\boldsymbol{K}}(\%)$ & $\boldsymbol{k}\left(\mathrm{W} \mathrm{m}^{-\mathbf{1}} \mathbf{K}^{-\mathbf{1}}\right)$ & $\boldsymbol{A}\left(\boldsymbol{\mu} \mathbf{W ~ m}^{-\mathbf{3}}\right)$ \\
\hline Host rock & 1.61 & 4.65 & 1.64 & 3.0 & 0.94 \\
Intrusion & 4.9 & 56 & 5.59 & 2.24 & 5.53 \\
\hline
\end{tabular}

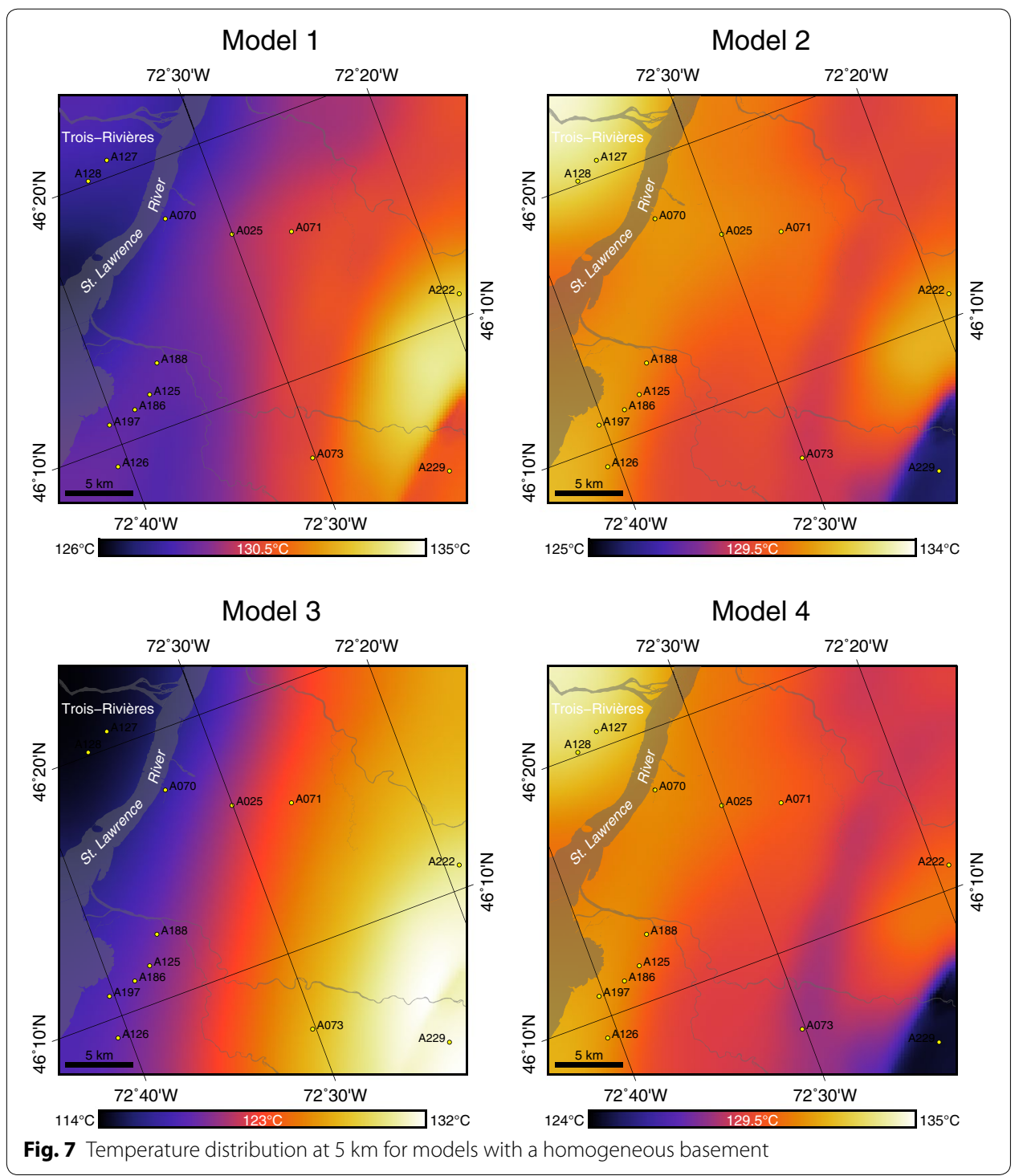

\section{Results and discussion}

\section{Homogeneous basement}

Figure 7 shows the temperature at $5 \mathrm{~km}$ for the different homogeneous basement models. The first observable trend is the relative temperature in the Trois-Rivières vicinity (where basement rocks are predominent), which is colder for Models 1 and 3, and warmer for Models 2 and 4, this for lower heat production in Models 1 and 3 but for lower heat flow at the bottom for Models 2 and 4. Thus, not surprisingly, the effect of 


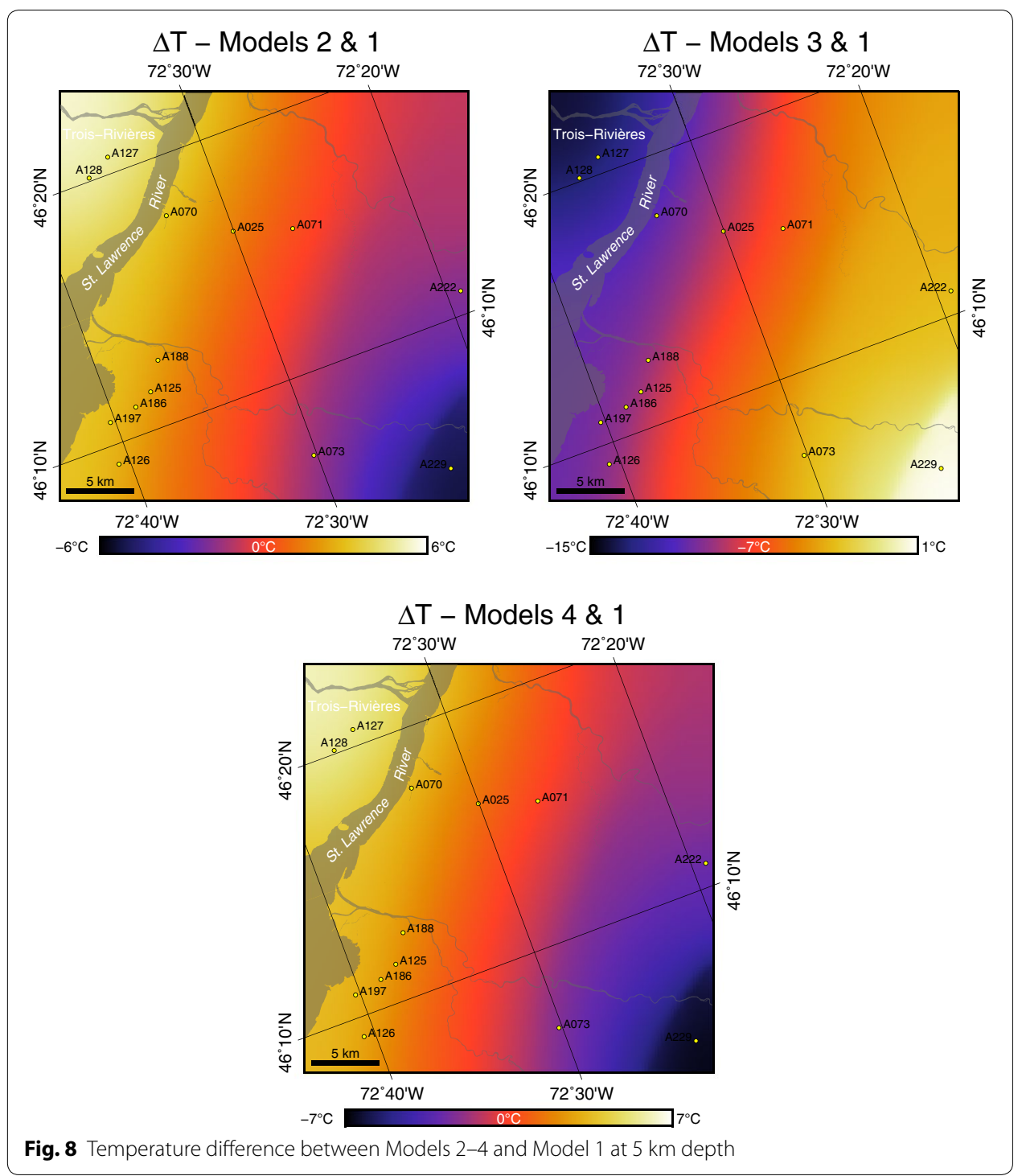

heat production is counterbalanced by heat flow at the bottom boundary: models with high heat production have a better fit to the available data with lower heat flow at the bottom. On the other hand, Models 1 and 4 have the highest temperature, followed by Model 2 and Model 3. This might appear surprising, because basement rocks in Model 2 have the highest value of heat production and Model 3 the highest value of heat flow at the bottom boundary. However, Model 2 also has the second lowest thermal conductivity and Model 3 has the highest thermal conductivity (respectively, 3 and $3.8 \mathrm{~W} \mathrm{~m}^{-1} \mathrm{~K}^{-1}$ for Models 1 and 3 vs 2.7 and $2.5 \mathrm{~W} \mathrm{~m}^{-1} \mathrm{~K}^{-1}$ for Models 2 and 4). These observations thus show that the thermal conductivity of the basement rocks has a significant impact on temperature distribution, regardless of heat production. It is, therefore, equally important to accurately determine both parameters to correctly assess the geothermal potential of a given area.

The difference between Models $2-4$ and Model 1 at $5 \mathrm{~km}$ depth is shown in Fig. 8. The maximum difference with Model 1 is $15^{\circ} \mathrm{C}$ (Model 3), with a range of $22^{\circ} \mathrm{C}(-15$ to 

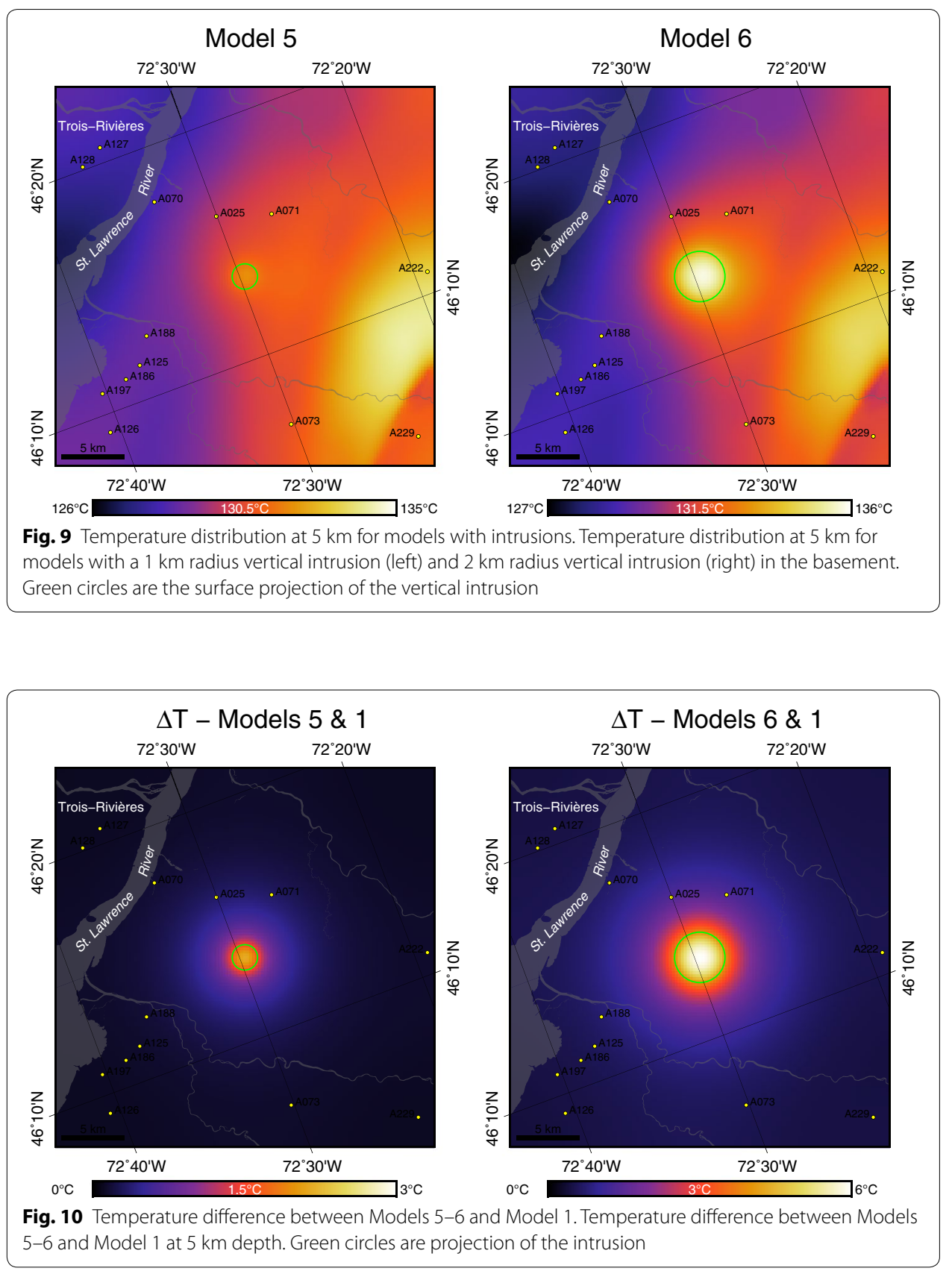

$7{ }^{\circ} \mathrm{C}$ ) if all scenarios are considered. Such a difference is important in the context of electricity production, because it can imply drilling deeper than expected may be required to meet specific temperature requirements.

\section{Effect of an intrusion in the basement}

As shown in Figs. 9 and 10, the influence of a relatively hot intrusion is rather limited, both spatially and in terms of temperature increase. For the smaller intrusion, the temperature increase at $5 \mathrm{~km}$ depth is only $3^{\circ} \mathrm{C}$. Moreover, although the larger intrusion is four times bigger than the smaller, the temperature increase is only $6^{\circ} \mathrm{C}$. In Addition, 


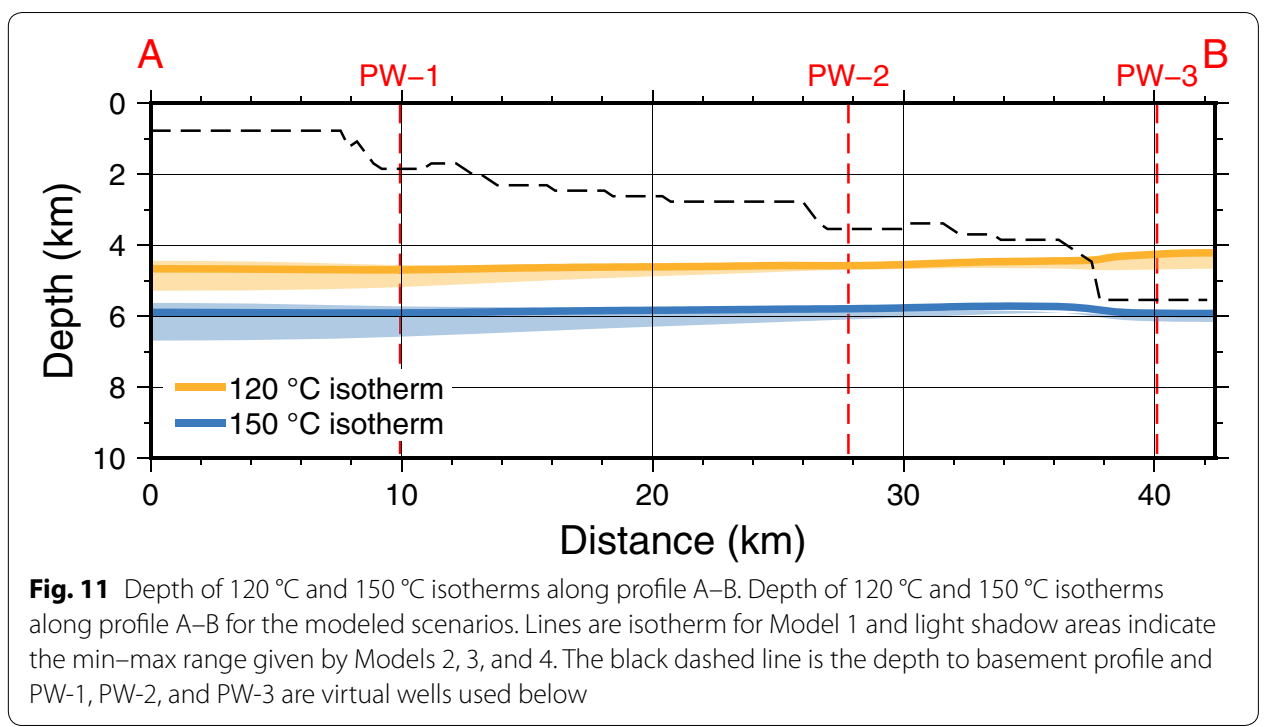

the spatial extent of the anomaly is mostly limited to the location of the intrusion. It thus appears that "hot" intrusions are of limited interest as geothermal exploration targets.

\section{Effect of bottom boundary condition}

At this point in the study, we examine the choice of the bottom boundary condition. In addition to the basement parameters, the boundary condition obviously plays a significant role in affecting the temperature distribution at depth, but to what quantitative extent? Figure 11 shows the $120^{\circ} \mathrm{C}$ and $150^{\circ} \mathrm{C}$ isotherms as function of depth for Model 1 (thick lines) and the range of depths for all models (shaded areas). There is a significant difference in isotherm depth between the difference models, with up to a $\mathrm{km}$ in depth difference in the northern part. In a given geothermal project, a poor estimation of this boundary condition would likely have dramatic impact on drilling costs.

Figure 12 shows a comparison between the simulated temperature for Model 1 under different bottom boundary conditions, with the measured temperature obtained from the drill stem tests in wells A126, A188, A197 and A222. This figure also indicates that the choice of the boundary condition value has a strong influence on the modeled temperatures at depth. This emphasizes the importance of having high quality data to calibrate the model.

\section{"Thermal blanket" effect of the sedimentary rocks}

Because sedimentary rocks usually have a relatively low thermal conductivity, they behave as a "thermal blanket", preserving the heat in the rocks at depth (Beardsmore 2005). We examine this effect taking Models 1,2 and 3 as examples. Figure 13 shows temperature profiles at three virtual wells located along profile $A B$, as illustrated in Figs. 5 and 11. Figure 13 shows that the temperature gradient in the sedimentary rocks is stronger than in the basement for Models 1 and 3, and especially for Model 3 in which the thermal conductivity of the basement is relatively higher. The opposite can be observed for Model 2, which has the lowest thermal conductivity but the highest heat 


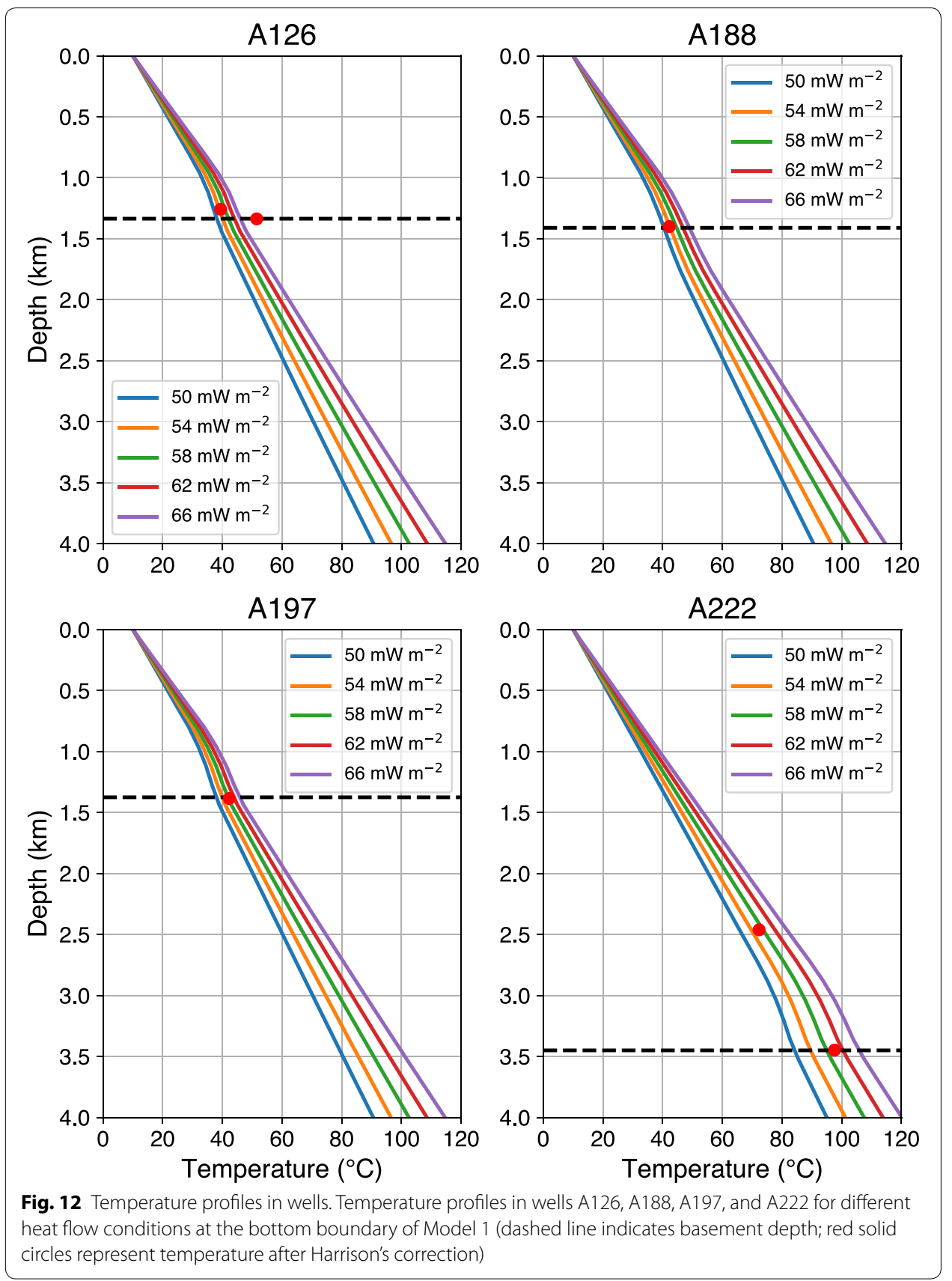

production. Thus, the thermal blanket effect is strongly controlled by the contrast in thermal conductivity. The inflection point varies in depth depending on thickness of the sedimentary cover, with an advantage at well PW-3. However, although the difference in sedimentary cover thickness is almost $4000 \mathrm{~m}$ between PW-1 and PW-3, the difference in inflection point depth is about $1500 \mathrm{~m}$, i.e., the so-called blanket effect is not as strong as might be expected at first. This can be attributed to the fact that the topography of the basement is irregular, with a large "step" not far from well PW-3 (see Fig. 11, and that lateral effects influence the thermal response. Through this case study, it appears that the benefit of the insulating effect of the sedimentary cover can be significant, but that it 


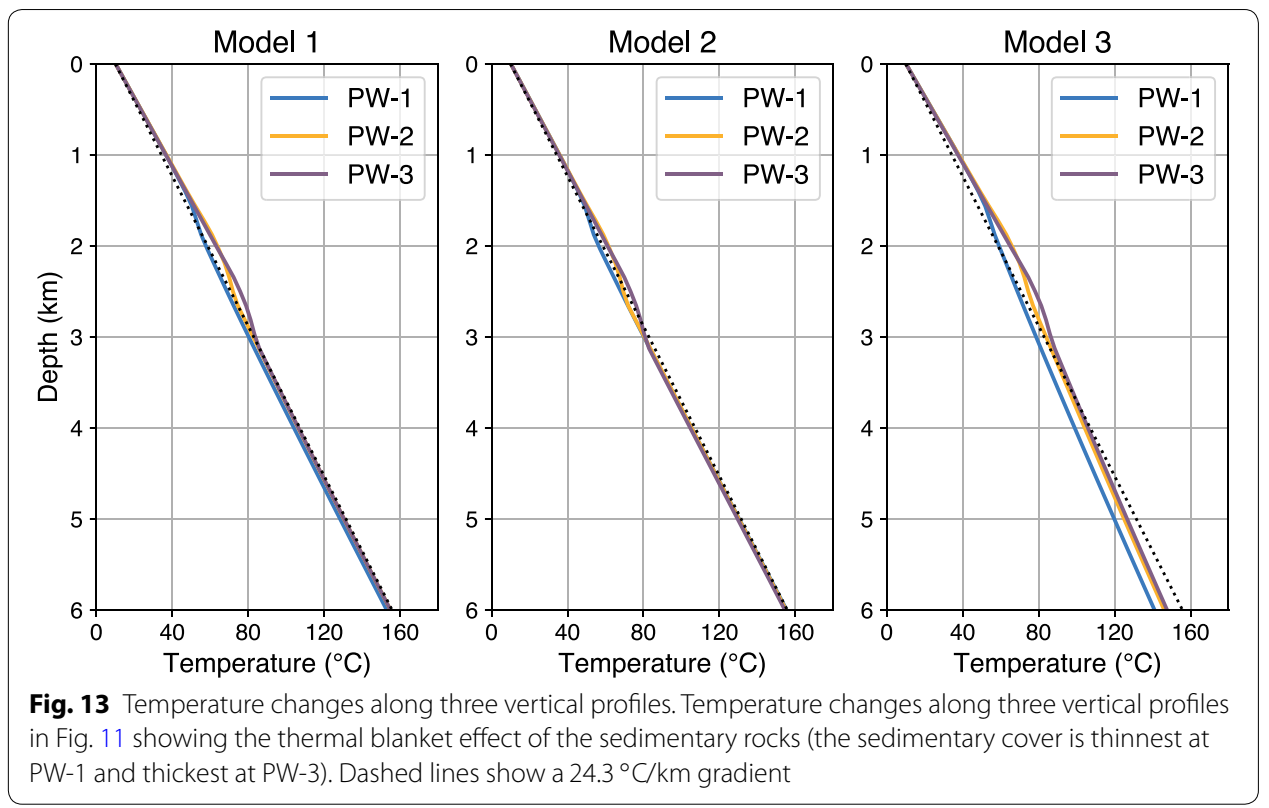

strongly depends on the contrast in thermal conductivity between the basement and the cover, as well as on the structural context.

\section{Surface heat flow}

Surface heat flow values computed from borehole data in the study area are given by Bédard et al. (2016). These data are compared with vertical heat flow computed from the results of the modeling with Underworld2. Figure 14 shows maps of surface heat flow for the six modeled scenarios, together with 18 data points from Bédard et al. (2016). The general agreement is best for the model with a basement representative of the Parc des Laurentides domain (Model 3), followed by models corresponding to the PortneufMauricie domain (Models 1, 5, and 6). More specifically, the rRMSE between data points from Bédard et al. (2016) and modeled surface heat flow is 13\% for Model 1, 15\% for Model 2, 11\% for Model 3, 17\% for Model 4, 13\% for Model 5 and 13\% for Model 6. These results should, however, be considered carefully, as the average of the borehole data $\left(76 \mathrm{~mW} \mathrm{~m}^{-2}\right)$ is much higher than the interpolated value that can be seen in the map of Fig. $1\left(\approx 55 \mathrm{~mW} \mathrm{~m}^{-2}\right)$, and Model 3 also has the worst rRMSE fit with the bottom hole temperature and regional gradient.

Comparisons between Model 6 and Model 1 reveal that, although the top of the large intrusion is $2.4 \mathrm{~km}$ below the surface, it produces sufficient heat to alter the temperature gradient up to the surface, and thus affects the heat flow at the surface. It is interesting to note, however, that the heat flow is lower for Model 6, which is counterintuitive. It is found that the presence of the intrusion slightly decreases the temperature gradient in the sedimentary cover, and thus decreases the heat flow at the surface, as shown in Fig. 15. Interpretation of temperature at depth from surface heat flow data is, therefore, a delicate matter. 


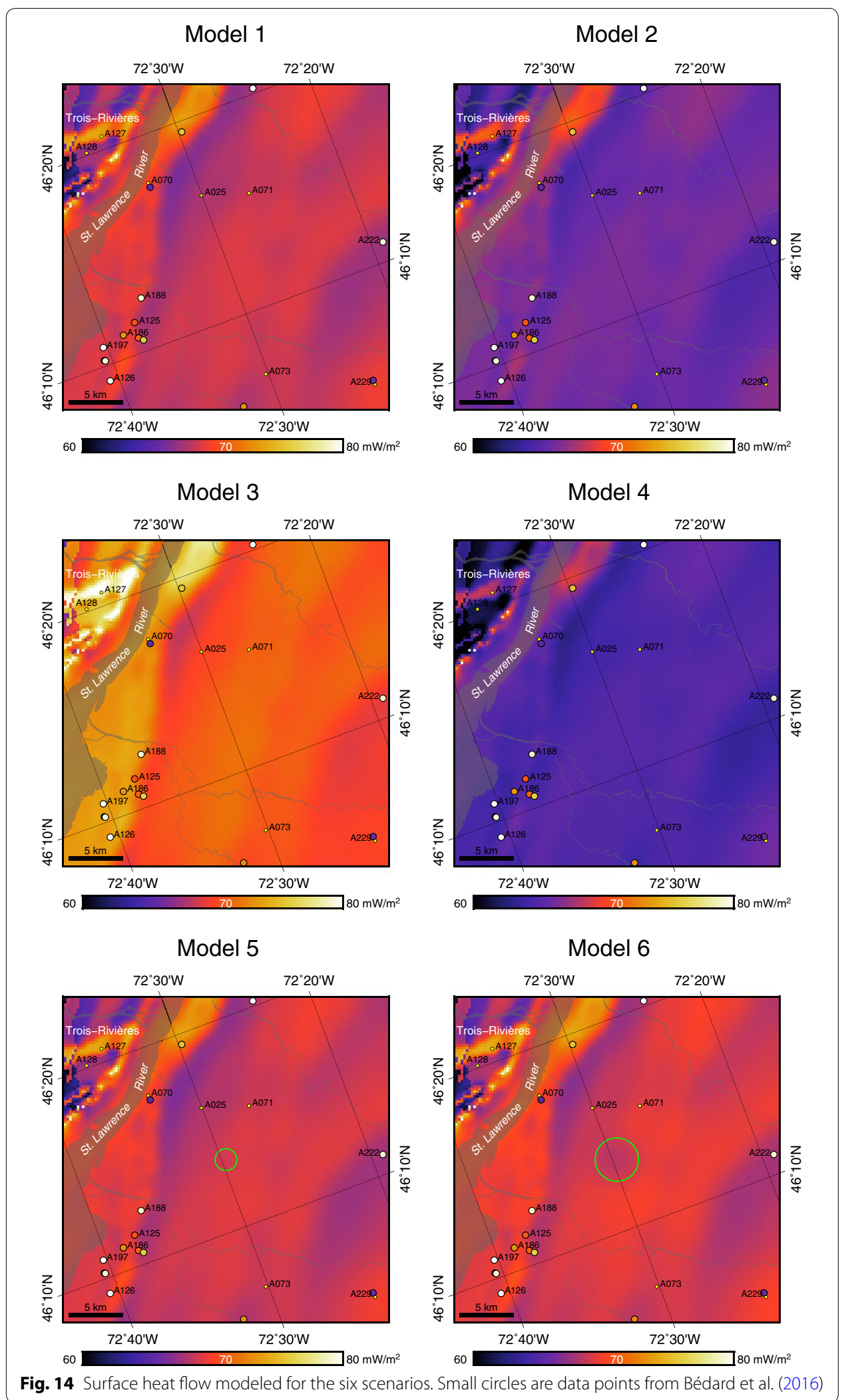



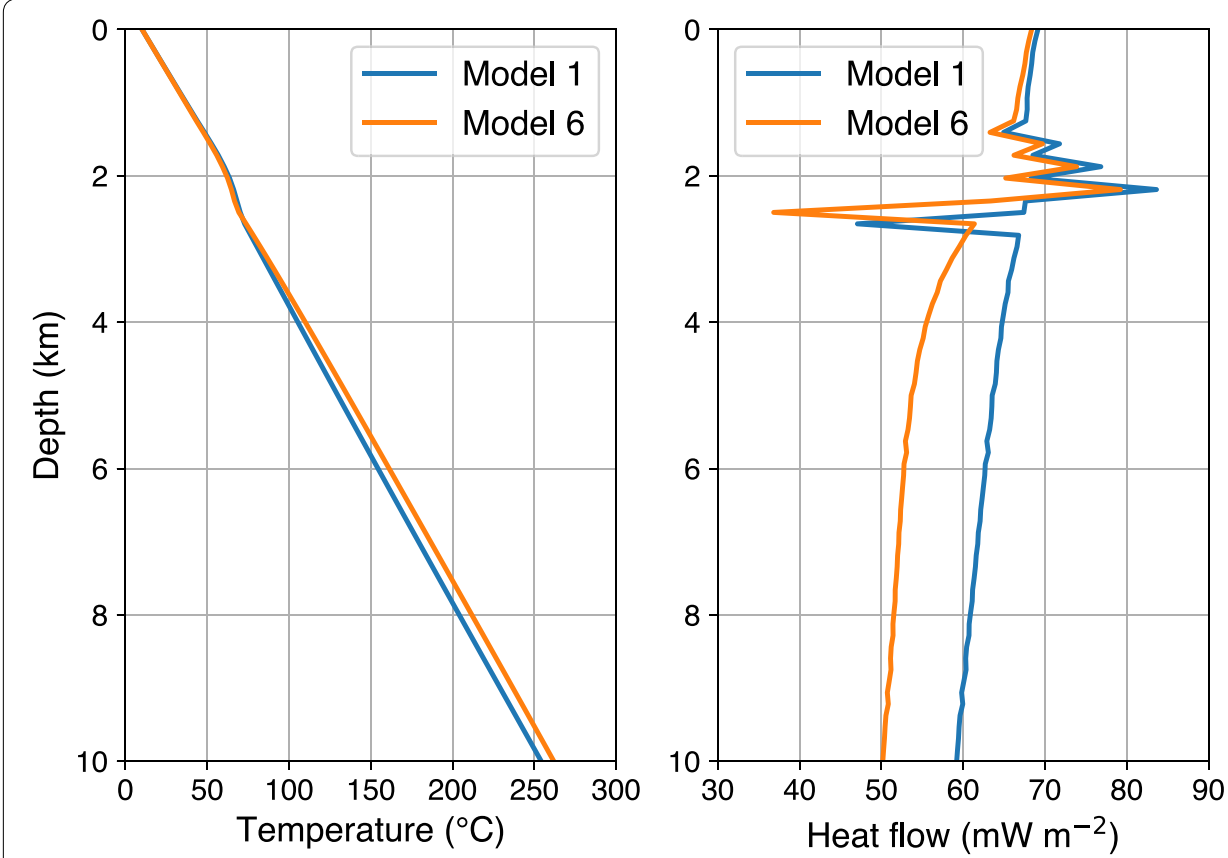

Fig. 15 Temperature and heat flow profiles at the center of Models 1 and 6

\section{Conclusions}

The main conclusions that can be drawn from this study are:

1 Statistical analysis of radiogenic element concentrations suggests that the radiogenic heat production south of Trois-Rivières is in the range of $0.34-3.24 \mu \mathrm{W} \mathrm{m}^{-3}, 0.94-$ $5.83 \mu \mathrm{W} \mathrm{m}^{-3}$ for the Portneuf-Mauricie domain, $0.02-4.13 \mu \mathrm{W} \mathrm{m}^{-3}$ for the Morin Terrane, especially its Shawinigan domain, $0.34-1.96 \mu \mathrm{W} \mathrm{m}{ }^{-3}$ for the Parc des Laurentides domain.

2 The distribution of temperature is affected by many factors, e.g., thermal conductivity, density, and concentration of radioelements in sedimentary rocks and basement, thickness of sedimentary cover, and structural context. For the modeled scenarios, temperature is highest in Models 1 and 4 (respectively, PM and well data basement), because it has the highest thermal conductivity, followed by Model 2 (Morin Terrane) and by Model 3 (PDLD basement). At a depth of $5 \mathrm{~km}$, the maximum difference with Model 1 is $15^{\circ} \mathrm{C}$ (with Model 3), and the range of difference is $22^{\circ} \mathrm{C}(-15$ to $7^{\circ} \mathrm{C}$ ) if all scenarios are considered.

3 Thick Cambro-Ordovician sedimentary rocks in this region may limit heat loss to the surface by virtue of the so-called "thermal blanket" effect. The benefit of this insulating effect can be significant, but it strongly depends on the contrast in thermal conductivity between the basement and the cover, as well as on the structural context, and less on heat production in the basement.

4. The boundary condition value imposed at the bottom boundary of the model plays a significant role in controlling the distribution of temperature. Depending on basement rock parameters, values in the range [52-62] $\mathrm{mW} \mathrm{m}^{-2}$ yield comparable fit to the regional temperature gradient, bottom hole temperature data and surface heat 
flow data. Moreover, heat production values in the models are counterbalanced by heat flow at the bottom boundary.

5 The effect of hot intrusions in the basement is relatively modest and localized in terms of temperature increase. The presence of intrusions underneath the sedimentary cover may also decrease the heat flow at the surface, and caution should be taken when using surface heat flow as an exploration variable.

The sensitivity of model outcomes to small changes in input parameters shows that better constrained input parameters are required to establish with certainty the nature of basement to our study area. Computed and measured heat flow models for PortneufMauricie domain basement beneath our study area are, however, compatible with the results of preliminary geophysical interpretations that ca. $35 \mathrm{~km}$ dextral transcurrent displacement may have occurred on late Grenvillian ductile shear zones beneath the northern St. Lawrence platform (Gicquel, unpublished data; Gicquel et al. 2015). Model results can, nevertheless, be applied to adjacent areas where the nature of basement domains is better defined.

A limitation of the present study lies in the assumption that, except for the models with intrusions, the basement is homogeneous. The input parameters, e.g., concentration of radiogenic elements, thermal conductivity, and density, used in these simulation models are derived from measurements made on different types of rocks, both from the St. Lawrence Lowlands and the geological domains surrounding the city of Trois-Rivières, and exhibit a broad range of values. Besides this, some parameters are poorly constrained due to the limited number of available data. Therefore, the selected scenarios do not encapsulate the variability that is likely encountered in reality. For this reason, work is underway to generate models with stochastic distributions of physical properties that are representative of the spatial variability observed in the outcropping rocks for the different domains considered in the study. This will in turn allows establishing ranges of possible temperatures at depth for the different scenarios.

\footnotetext{
Abbreviations

AMCG: anorthosite-mangerite-charnockite-granite; BK: Beekmantown; MT: Morin Terrane; PDLD: Parc des Laurentides domain; PM: Portneuf-Mauricie; PO: Potsdam; SR-LO-QT: Sainte-Rosalie-Lorraine-Queenston; Tr-BR-Ch: Trenton-Black River-Chazy; TSZ: Tawachiche shear zone.
}

\section{Authors' contributions}

$\mathrm{HL}$ gathered data, prepared the model, ran Underworld2 simulations and wrote the first draft of the manuscript. BG reviewed the model and the numerical simulations, ran additionnal Underworld2 simulations, and revised the manuscript. $\mathrm{LBH}$ reviewed the manuscript and completed the section on Geological setting. SMQ and JM contributed to the elaboration of the numerical model. All authors read and approved the final manuscript.

\footnotetext{
Author details

${ }^{1}$ Centre - Eau Terre Environnement, Institut national de la recherche scientifique, 490 rue de la Couronne, Québec, QC G1K 9A9, Canada. ${ }^{2}$ State Key Laboratory of Geomechanics and Geotechnical Engineering, Institute of Rock and Soil Mechanics, Chinese Academy of Sciences, Wuhan 430071, China. ${ }^{3}$ Monash eResearch Centre, Monash University, Clayton, VIC 3800, Australia. ${ }^{4}$ School of Mathematical Sciences, Monash University, Clayton, VIC 3800, Australia.
}

\section{Acknowledgements}

We would like to thank the reviewers for their constructive comments. We would also like to show our appreciation to Jean-Claude Mareschal at the Université du Québec à Montréal, Karine Bédard, Aurélie Gicquel, Félix-Antoine Comeau, Jasmin Raymond, Emmanuelle Millet, Maher Nasr, and Jean-Philippe Drolet from INRS-ETE. Vasile Minea from HydroQuébec gave us much help with the collection of basic geothermal data, and Jennifer Levett from Mira Geoscience Ltd. of Montréal gave us invaluable help in technical support of GOCAD software, to Louis Moresi, Fabio Capitanio, Julian Giordani, Jerico Revote, Owen Kaluza and Ben Mather for their guidance in using the Underworld2 software. We also give our thanks to Adrien Bouffard at the Ministère de l'Énergie et des Ressources naturelles (MERN) who helped in collecting the basement rock samples. 


\section{Competing interests}

The authors declare that they have no competing interests.

\section{Availability of data and materials}

The datasets used and/or analysed during the current study are available from the corresponding author on reasonable request.

\section{Funding}

Research was funded by the Natural Sciences and Engineering Research Council of Canada and IREQ/Hydro Québec (Grant RDCPJ 451432-13).

\section{Publisher's Note}

Springer Nature remains neutral with regard to jurisdictional claims in published maps and institutional affiliations.

Received: 12 July 2018 Accepted: 15 December 2018

Published online: 26 December 2018

\section{References}

Beardsmore GR. Thermal modeling of the Hot Dry Rock geothermal resource beneath GEL99 in the Cooper Basin, South Australia. In: World Geothermal Congress 2005. 2005. http://www.geothermal-energy.org/pdf/IGAstandard/ WGC/2005/1634.pdf. Accessed 22 Dec 2018.

Bédard K, Comeau F-A, Malo M. Modélisation géologique 3D du basin des Basses-Terres du Saint-Laurent. Research Report INRSCO2-2013-V1.5, Institut national de la recherche scientifique. 2013. http://espace.inrs.ca/1643/1/R0014 39.pdf. Accessed 22 Dec 2018.

Bédard K, Comeau F-A, Millet E, Raymond J, Malo M, Gloaguen E. Évaluation des ressources géothermiques du bassin des Basses-Terres du Saint-Laurent. Research Report INRS-1659, Institut national de la recherche scientifique. 2016. http://espace.inrs.ca/4845/1/R001659.pdf. Accessed 22 Dec 2018.

Bédard K, Malo M, Comeau F-A. CO 2 geological storage in the province of Québec, Canada. Capacity evaluation of the St. Lawrence Lowlands basin. Energy Procedia. 2013;37:5093-100.

Bernstein L. The Lower Ordovician Beekmantown Group, Québec and Ontario. Ph.D. thesis, Université de Montréal, Montréal. Canada. 1991.

Capuno VT, Maria RBS, Minguez EB. Tiwi geothermal field, Philippines: 30 years of commercial operation. In: Proceedings World Geothermal Congress 2010, Bali, Indonesia. 2010.

Castonguay S, Dietrich J, Lavoie D, Laliberte JY. Structure and petroleum plays of the St. Lawrence Platform and Appalachians in southern Quebec: insights from interpretation of MRNQ seismic reflection data. Bull Can Petrol Geol. 2010;58(3):219-34.

Charlier B, Namur O, Malpas S, de Marneffe C, Duchesne JC, Vander Auwera J, Bolle O. Origin of the giant Allard Lake ilmenite ore deposit (Canada) by fractional crystallization, multiple magma pulses and mixing. Lithos. 2010;117(1-4):119-34.

ClarkTH. Région de Montréal area. Geological Report RG-152, Ministère des Richesses Naturelles, Québec. 1972.

Comeau F-A, Bédard K, Malo M. Les régions de Nicolet et de Villeroy: état des connaissances pour le stockage géologique du CO 2 . Research Report R1332, INRS-ETE. 2012. http://espace.inrs.ca/532/1/R001332.pdf. Accessed 22 Dec 2018.

Corrigan D. Mesoproterozoic evolution of the south-central Grenville orogen: structural, metamorphic, and geochronologic constraints from the Mauricie transect. Ph.D. thesis, Carleton University; 1995. https://curve.carleton.ca/df84d eaf-2f8e-4ba2-9c7e-58c98d5faff6. Accessed 22 Dec 2018.

Corrigan D, van Breemen O. U-Pb age constraints for the lithotectonic evolution of the Grenville province along the Mauricie transect, Quebec. Can J Earth Sci. 1997;34(3):299-316.

Corriveau L, van Breemen O. Docking of the Central Metasedimentary Belt to Laurentia in geon 12: evidence from the 1.17-1.16 Ga Chevreuil intrusive suite and host gneisses, Quebec. Can J Earth Sci. 2000;37(2):253-69.

Costain JK, Glover L, Sinha AK. Low-temperature geothermal resources in the eastern United-States. Eos Trans Am Geophys Union. 1980;61(1):1-3.

Davidson A. Identification of ductile shear zones in the south-western Grenville Province of the Canadian Shield. In: Kroner A, Greiling R, editors. Precambrian Tectonics Illustrated. Stuttgart: Schweizerbart'sche Verlagsbuchhandlung; 1984. p. 263-79.

De Souza S, Tremblay A, Ruffet G. Taconian orogenesis, sedimentation and magmatism in the southern Quebecnorthern Vermont Appalachians: Stratigraphic and detrital mineral record of lapetan suturing. Am J Sci. 2014;314(7):1065-103.

Drury MJ, Jessop AM, Lewis TJ. The thermal nature of the Canadian Appalachian crust. Tectonophysics. 1987;133:1-14.

Dufréchou G. Aeromagnetic signature of an exhumed double dome system in the sw Grenville Province (Canada). Terra Nova. 2017;29(6):363-71.

Dufréchou G, Harris LB, Corriveau L. Tectonic reactivation of transverse basement structures in the Grenville orogen of SW Quebec, Canada: insights from gravity and aeromagnetic data. Precambrian Res. 2014;241:61-84.

Emslie RF, Ermanovics IF. Major rock units of the Morin Complex, southwestern Quebec. Paper 74-48, Geological Survey of Canada. 1975. https://doi.org/10.4095/102555

Emslie RF, Hunt PA. Ages and petrogenetic significance of igneous mangerite-charnockite suites associated with massif anorthosites, Grenville Province. J Geol. 1990;98(2):213-31.

Feininger T, Goodacre AK. The eight classical Monteregian hills at depth and the mechanism of their intrusion. Can J Earth Sci. 1995;32(9):1350-64. 
Ford KL, Savard M, Dessau J-C, Pellerin E, Charbonneau BW, Shives BK. The role of gamma-ray spectrometry in radon risk evaluation: a case history from Oka, Quebec. Geosci Can. 2001;28(2):59-64.

Fou JTK. Thermal conductivity and heat flow at St. Jerôme, Quebec. M.Sc. thesis, McGill University. 1969.

Gautier E. Géochimie et pétrologie du complexe de La Bostonnais et du gabbro du Lac Lapeyrère. M.Sc. thesis, Université Laval; 1993.

Gicquel A, Harris LB, Groulier PA. Interpretation of new aeromagnetic data and implications for geothermal power from a suite of radiogenic units beneath the Appalachian sedimentary cover. In: Québec Mines, Québec, Canada; 2015. http://gq.mines.gouv.qc.ca/documents/examine/DV201506/DV201506.pdf. Accessed 22 Dec 2018.

Globensky Y. Géologie des Basses-Terres du Saint-Laurent. Report MM85-02, Ministère de l'Énergie et des Ressources du Québec. 1987.

Grasby SE, Allen DM, Bell S, Chen Z, Ferguson G, Jessop A, Kelman M, Ko M, Majorowicz J, Moore M, Raymond J, Therrien R. Geothermal energy resource potential of Canada. Open File 6914, Geological Survey of Canada. 2012. https://doi. org/10.4095/291488.

Hébert C, Nadeau L. Géologie de la région de Talbot (Portneuf), carte 2213, échelle 1:50000. Étude 95-01, Ministère des Ressources naturelles, Québec. 1995.

Hersi OS, Lavoie D, Nowlan GS. Reappraisal of the Beekmantown group sedimentology and stratigraphy, montreal area, southwestern Quebec: implications for understanding the depositional evolution of the Lower-Middle Ordovician Laurentian passive margin of eastern Canada. Can J Earth Sci. 2003;40(2):149-76.

Higgins MD, van Breemen O. Three generations of anorthosite-mangerite-charnockite-granite (AMCG) magmatism, contact metamorphism and tectonism in the Saguenay-Lac-Saint-Jean region of the Grenville Province, Canada. Precambrian Res. 1996;79(3-4):327-46.

Hillis R, Hand M, Mildren S, Morton J, Reid P, Reynolds S. Hot Dry Rock geothermal exploration in Australia: Application of the in situ stress field to Hot Dry Rock geothermal energy in the Cooper Basin. In: PESA Eastern Australasian Basins Symposium II, Adelaide, South Australia; 2004. p. 415-423.

Hofmann HJ. Stratigraphy of the Montreal area. Excursion Guidebook B-O3, 24th International Geological Congress. 1972.

Horspool N, Lescinsky DT, Kirkby AL, Meixner AJ. The Cooper Basin Region 3D Map Version 2: Thermal modeling and Temperature Uncertainty. 2012. http://pid.geoscience.gov.au/dataset/ga/74291. Accessed 22 Dec 2018.

Jaupart C, Mareschal JC, Guillou-Frottier L, Davaille A. Heat flow and thickness of the lithosphere in the Canadian Shield. J Geophys Res Solid Earth. 1998;103(B7):15269-86.

Jaupart C, Mareschal J-C. Heat Generation and Transport in the Earth. Cambridge: Cambridge University Press; 2011. p. 464.

Jessop AM, Allen VS, Bentkowski W, Burgess M, Drury M, Judge AS, Lewis T, Majorowicz J, Mareschal JC, Taylor AE. The Canadian geothermal data compilation. Open File 4887, Geological Survey of Canada. 2005.

Kearey P. An interpretation of the gravity field of the Morin anorthosite complex, southwest Quebec. Geol Soc Am Bull. 1978;89(3):467-75.

Konstantinovskaya E, Malo M, Castillo DA. Present-day stress analysis of the St. Lawrence Lowlands sedimentary basin (Canada) and implications for caprock integrity during $\mathrm{CO}_{2}$ injection operations. Tectonophysics. 2012;518:119-37.

Kumarapeli PS. Vestiges of lapetan rifting in the craton west of the northern Appalachians. Geosci Can. 1985;12(2):54-9.

Lavoie D, Chi GX. Lower Paleozoic foreland basins in eastern Canada: tectono-thermal events recorded by faults, fluids and hydrothermal dolomites. Bull Can Petrol Geol. 2010;58(1):17-35.

Lavoie D, Pinet N, Castonguay S, Dietrich J, Giles P, Fowler M, Thériault R, Laliberté JY, Peter S, Hinds S, Hicks L, Klassen H. Hydrocarbon systems in the Paleozoic basins of eastern Canada. Open File 5980, Geological Survey of Canada. 2009.

Lavoie D, Rivard C, Lefebvre R, Sejourne S, Theriault R, Duchesne MJ, Ahad JME, Wang B, Benoit N, Lamontagne C. The Utica Shale and gas play in southern Quebec: geological and hydrogeological syntheses and methodological approaches to groundwater risk evaluation. Int J Coal Geol. 2014;126:77-91.

Lee YM, Deming D. Evaluation of thermal conductivity temperature corrections applied in terrestrial heat flow studies. J Geophys Res Solid Earth. 1998;103(B2):2447-54.

Majorowicz J, Grasby SE. Heat flow, depth-temperature variations and stored thermal energy for enhanced geothermal systems in Canada. J Geophys Eng. 2010;7(3):232-41.

Majorowicz J, Minea V. Geothermal energy potential in the St. Lawrence River area, Quebec. Geothermics. 2012;43:25-36.

Majorowicz J, Minea V. Geothermal anomalies in the Gaspésie Peninsula and Madeleine Islands, Québec. Trans GRC. 2013:37:1-12.

Malo M, Aznar J-C, Bédard K, Claprood M, Comeau F-A, Konstantinovskaya E, Giroux B, Moutenet J-P, Tran Ngoc TD. Rapport synthèse 2008-2013, Chaire de recherche sur la séquestration géologique du $\mathrm{CO}_{2}$. Research Report 1492, INRS-ETE. 2014. http://espace.inrs.ca/2092/1/R001492.pdf. Accessed 22 Dec 2018.

Mansour J, Kaluza O, Giordani J, Beucher R, Farrington R, Kennedy G, Moresi L, Velic M, Beall A, Sandiford D. underworldcode/underworld2: v2.6.0b. 2018. https://doi.org/10.5281/zenodo.1475861.

Mareschal JC. Données géothermiques. 2018.

Mareschal JC, Jaupart C. Radiogenic heat production, thermal regime and evolution of continental crust. Tectonophysics. 2013:609:524-34.

Mareschal JC, Jaupart C, Gariepy C, Cheng LZ, Guillou-Frottier L, Bienfait G, Lapointe R. Heat flow and deep thermal structure near the southeastern edge of the Canadian Shield. Can J Earth Sci. 2000;37(2):399-414.

Martignole J, Schrijver K. Anorthosite-farsundite complexes in the southern part of the Grenville Province. Geosci Can. 1977:4(3):137-43

Minea V, Majorowicz J. Assessment of enhanced geothermal systems potential in Québec, Canada. In: AAPG/SPE/SEG HEDBERG Research Conference Enhanced Geothermal Systems, Napa, California. 2011. http://www.searchandd iscovery.com/pdfz/abstracts/pdf/2011/hedberg-california/abstracts/ndx_minea.pdf.html Accessed 22 Dec 2018.

Minea V, Majorowicz J. Preliminary assessment of deep geothermal resources in Trois-Rivières area, Québec. Trans Geotherm Resour Council. 2012;36:709-15.

Misener AD, Thompson LGD, Uffen RJ. Terrestrial heat flow in Ontario and Quebec. Trans Am Geophys Union. 1951;32(5):729. 
Moresi L, Quenette S, Lemiale V, Meriaux C, Appelbe B, Muhlhaus HB. Computational approaches to studying non-linear dynamics of the crust and mantle. Phys Earth Planet Inter. 2007;163(1-4):69-82.

Nadeau L, Brouillette P. Carte structurale de la région de La Tuque (SNRC 31P), Province de Grenville, Québec. Open File 2938, Geological Survey of Canada. 1994.

Nadeau L, Brouillette P. Carte structurale de la région de Shawinigan (SNRC 311), Province de Grenville, Québec. Open File 3012, Geological Survey of Canada. 1995.

Nadeau L, van Breemen O. Do the 1.45-1.39 Ga Montauban group and the La Bostonnais complex constitute a Grenvillian accreted terrane. In: Geological Association of Canada, Programs with Abstracts, vol. 19, p. 81; 1994.

Nadeau L, van Breemen O. U-Pb Zircon age and regional setting of the Lapeyrère gabbronorite, Portneuf-Mauricie region, south central Grenville Province, Quebec. Current Research 2001-F6, Geological Survey of Canada. 2001. https://doi.org/10.4095/212673.

Nadeau L, Brouillette P, Hébert C. Arc magmatism, continental collision and exhumation: the mesoproterozoic evolution of the south-central Grenville Province, Portneuf-Mauricie region, Quebec, Field Trip B3. 2008. http://www.friendsoft heGrenville.org/fog_2010.pdf. Accessed 22 Dec 2018.

Nadeau L, van Breemen O, Hébert C. Géologie, âge et extension géographique du groupe de Montauban et du complexe de La Bostonnais. Report DV 92-03, Ministère de l'énergie et des Ressources, Québec. 1992.

Nasr M. Évaluation des propriétés thermiques de la séquence des Basses-Terres du Saint-Laurent: Mesures au laboratoire et approche diagraphique. M.Sc. thesis, Institut National de la Recherche Scientifique-Centre Eau Terre Environnement. 2016. http://espace.inrs.ca/4637/. Accessed 22 Dec 2018.

Owen JV, Greenough JD. Influence of Potsdam sandstone on the trace element signatures of some 19th-century American and Canadian glass: Redwood, Redford, Mallorytown, and Como-Hudson. Geoarchaeology. 2008;23(5):587-607.

Paradis N. Modélisation gravimétrique et magnétique des intrusions gabbronoritiques de Lapeyrère et d'édouard, région de Portneuf-Mauricie, Province de Grenville, Québec. M.Sc. thesis, Institut National de la Recherche ScientifiqueCentre Eau Terre Environnement. 2004.

PeckWH. Reconnaissance geochronology and geochemistry of the Mont-Tremblant gneiss of the Morin terrane, Grenville Province, Quebec. Geosphere. 2012;8(6):1356-65

Perozzi L, Raymond J, Asselin S, Gloaguen E, Malo M, Bégin C. Simulation géostatistique de la conductivité thermique: application à une region de la communauté métropolitaine de Montréal. Research Report R1663, Institut National de la Recherche Scientifique—Centre Eau Terre Environnement. 2016. http://espace.inrs.ca/3374/1/R001663.pdf. Accessed 22 Dec 2018.

Perry C, Rosieanu C, Mareschal JC, Jaupart C. Thermal regime of the lithosphere in the Canadian Shield. Can J Earth Sci. 2010;47(4):389-408.

Pinet C, Jaupart C, Mareschal JC, Gariepy C, Bienfait G, Lapointe R. Heat-flow and structure of the lithosphere in the eastern Canadian Shield. J Geophys Res Solid Earth. 1991;96(B12):19941-63.

Pinti DL, Beland-Otis C, Tremblay A, Castro MC, Hall CM, Marcil JS, Lavoie JY, Lapointe R. Fossil brines preserved in the St. Lawrence Lowlands, Quebec, Canada as revealed by their chemistry and noble gas isotopes. Geochim Cosmochim Acta. 2011;75(15):4228-43.

Quenette S, Xi YF, Mansour J, Moresi L, Abramson D. Underworld-GT applied to Guangdong, a tool to explore the geothermal potential of the crust. J Earth Sci. 2015;26(1):78-88.

Raymond J, Malo M, Comeau FA, Bédard K, Lefebvre R. Assessing the geothermal potential of the St. Lawrence Lowlands sedimentary basin in Quebec, Canada. In: IAH 2012 Congress, Niagara Falls, Canada; 2012. http://grrebs.ete.inrs.ca/ wp-content/uploads/2014/10/2012_Raymond_Assessing-the-geothermal-potential-of-the-St-Lawrence-Lowlandssedimentary-basin-in-Quebec.pdf. Accessed 22 Dec 2018.

Raymond J, Malo M, Tanguay D, Grasby S, Bakhteyar F. Direct utilization of geothermal energy from coast to coast: a review of current applications and research in Canada. In: World Geothermal Congress, Melbourne, Australia; 2015.

Rimando RE, Benn K. Evolution of faulting and paleo-stress field within the Ottawa Graben, Canada. J Geodyn. 2005;39(4):337-60.

Rivard P, Ollivier JP, Ballivy G. Characterization of the ASR rim — application to the Potsdam sandstone. Cem Concr Res. 2002;32(8):1259-67.

Rivers T. Lithotectonic elements of the Grenville Province: review and tectonic implications. Precambrian Res. 1997:86(3-4):117-54.

Rivers T. Tectonic setting and evolution of the Grenville orogen: an assessment of progress over the last 40 years. Geosci Can. 2015;42(1):77-124.

Rocher M, Tremblay A. L'effondrement de la plate-forme du Saint-Laurent : ouverture de lapetus ou de I'Atlantique ? Apport de la reconstitution des paléocontraintes dans la région de Québec (Canada). Comptes Rendus de I'Académie des Sciences-Series IIA-Earth and Planetary Science. 2001;333(3):171-8.

Rybach L. Radioactive heat-production in rocks and its relation to other petrophysical parameters. Pure Appl Geophys. 1976;114(2):309-17.

Rybach L. In: Hanel R, Rybach L, Stegena L editors. Determination of heat production rate. Dordrecht: Kluwer Academic Publishers; 1988. p. 125-142.

Sappin A-A. Pétrologie et métallogénie d'indices de Ni-Cu-éléments du Groupe du Platine du domaine de PortneufMauricie, Québec (Canada). Ph.D. thesis, Université Laval. 2012. https://doi.org/10.1139/E09-022.

Sappin A-A, Constantin M, Clark T. Les indices de Ni-Cu士EGP du domaine de Portneuf-Mauricie dans la Province de Grenville: un exemple de minéralisation magmatique mise en place dans un environnement d'arc magmatique. Open File 7610, Geological Survey of Canada. 2014. https://doi.org/10.4095/293908

Sappin A-A, Constantin M, Clark T, van Breemen O. Geochemistry, geochronology, and geodynamic setting of $\mathrm{Ni}-\mathrm{Cu}$ +/- PGE mineral prospects hosted by mafic and ultramafic intrusions in the Portneuf-Mauricie domain, Grenville Province, Quebec. Can J of Earth Sci. 2009:46(5):331-53.

Saull VA, Clark TH, Doig RP, Butler RB. Terrestrial heat flow in the St. Lawrence Lowland of Québec. CIM Bull. 1962;65:63-6.

Sekiguchi K. A method for determining terrestrial heat-flow in oil basinal areas. Tectonophysics. 1984;103(1-4):67-79. 
SIGÉOM: SIGÉOM Système d'information géominière du Québec. 2018. http://sigeom.mines.gouv.qc.ca. Accessed 22 Dec 2018.

SMU Geothermal Laboratory: SMU Node of the National Geothermal Data System. 2018. http://geothermal.smu.edu/ gtda/. Accessed 22 Dec 2018.

Soucy La Roche R. Histoire tectono-métamorphique de la zone de cisaillement Taureau orientale et ses implications pour l'exhumation de la croute moyenne dans la Province de Grenville. M.Sc. thesis, Université du Québec à Montréal. 2014.

Soucy La Roche R, Gervais F, Tremblay A, Crowley UL, Ruffet G. Tectono-metamorphic history of the eastern Taureau shear zone, Mauricie area, Québec: implications for the exhumation of the mid-crust in the Grenville Province. Precambrian Res. 2015;257:22-46.

Thériault R, Laliberté JY, Brisebois D, Rheault M. Fingerprinting of the Ottawa-Bonnechère and Saguenay grabens under the St. Lawrence Lowlands and Québec Appalachians: prime targets for hydrocarbon exploration. In: Geological Association of Canada, vol. 65. Halifax, Nova Scotia; 2005.

Thompson A. Geothermal development in Canada: Country update. In: World Geothermal Congress, Bali, Indonesia. 2010. http://www.geothermal-energy.org/pdf//GAstandard/WGC/2010/0116.pdf. Accessed 22 Dec 2018.

Thompson A, Bakhteyar F, Van Hal G. Geothermal industry development in Canada-country update. In: World Geothermal Congress, Melbourne, Australia; 2015.

Tremblay A, Long B, Masse M. Supracrustal faults of the St. Lawrence rift system, Quebec: kinematics and geometry as revealed by field mapping and marine seismic reflection data. Tectonophysics. 2003;369(3-4):231-52.

Vautour G, Pinti DL, Méjean P, Saby M, Meyzonnat G, Larocque M, Castro MC, Hall CM, Boucher C, Roulleau E, Barbecot F, Takahata N, Sano Y. 3H/3He, 14C and (U-Th)/He groundwater ages in the St. Lawrence Lowlands, Quebec, Eastern Canada. Chem Geol. 2015;413:94-106.

\section{Submit your manuscript to a SpringerOpen ${ }^{\circ}$ journal and benefit from:}

- Convenient online submission

- Rigorous peer review

- Open access: articles freely available online

- High visibility within the field

- Retaining the copyright to your article

Submit your next manuscript at $\gg$ springeropen.com 